\title{
ALIRAN, TIPOLOGI DAN TEORI PENDIDIKAN ISLAM
}

\author{
M. Nafiur Rofiq \\ Dosen Fakultas Tarbiyah, IAI Al - Falah As - sunniYyah Kencong \\ mnafiurrofiq@gmail.com
}

\begin{abstract}
The thought of Islamic education, from time to time, changes with the changing times with various factors. One of the factors that influence the change is the difference in the way of looking at the nature, purpose, methods and sources of Islamic education. In this case there are three main streams of Islamic education, namely conservative religious flow, rational religious flow, instrumental pragmatic flow and there are five typologies of Islamic education thought namely essentialist salafi perennials, perennial essentialist wahhabi, modernist typology, contextualphilosophical essentialist typology, reconstruction typology sausage based on tauhid.
\end{abstract}

Keywords: Islamic religious education, Islamic typology, Islamic education theory.

\begin{abstract}
ABSTRAK
Pemikiran pendidikan Islam, dari waktu ke waktu, mengalami perubahan seiring perubahan zaman dengan berbagai faktornya. Salah satu faktor yang mempengaruhi perubahan tersebut adalah perbedaan cara pandang dalam memaknai hakekat, tujuan, metode dan sumber pendidikan Islam. Dalam hal ini ada tiga aliran utama pendidikan islam yaitu aliran agamis konserfatif, aliran religius rasional, aliran pragmatis Instrumental dan ada lima tipologi pemikiran pendidikan islam yaitu tipologi perenial esensialis salafi, perenial esensialis wahabi, Tipologi modernis, Tipologi perenial esensialis kontekstual - falsifikatif, Tipologi rekontruksi sosisal berdasarkan tauhid.
\end{abstract}

Kata Kunci : Pendidikan Agama Islam, Tipologi Islam, Teori Pendidikan Islam

\section{PENDAHULUAN}

Mengkaji pemikiran pendidikan Islam, tidak bisa dilepaskan dari aspek kajian tentang filsafat pendidikan Islam, karena filsafat pendidikan merupakan titik permulaan dalam proses pelaksanaan pendidikan itu sendiri, disamping itu juga menjadi tulang punggung ke mana bagian-bagian yang lain dalam pendidikan itu bergantung dari segi tujuan-tujuan pendidikan, kurikulum pendidikan, metode mengajar, penilaian adminitrasi, alat-alat mengajar, dan beberapa aspek pendidikan lain yang memberinya arah, menunjuk jalan yang akan dilaluinya dan

FALASIFA, Vol. 10 Nomor 1 Maret 2019 | 153 


\section{Nafiur Rofiq}

meletakkan dasar-dasar serta prinsip-prinsip tempat tegaknya pendidikan tersebut.

Sebelum masuk dalam pembahasan tentang aliran-aliran dan teori-teori yang ada dalam Pendidikan Islam, sebaiknya diketahui terlebih dahulu tentang makna dan arti Filsafat Pendidikan Islam. Al-Syaibani menjelaskan bahwa filsafat pendidikan Islam adalah sebagai prinsip-prinsip dan berbagai kepercayaan yang berasal dari ajaran Islam atau sesuai dengan jiwa Islam yang mengandung kepentingan pelaksanaan dan bimbingan dalam bidang pendidikan. Filsafat pendidikan yang berdasarkan pada Islam ini tidak lain adalah pandangan dasar pendidikan yang bersumberkan ajaran Islam dan orientasi pemikirannya berdasarkan ajaran tersebut. Dari pengertian tersebut, berarti terdapat beberapa unsur dalam pendidikan Islam yaitu landasan-landasan pendidikan Islam berupa al-Qur'an dan as-Sunnah, bersifat filosofis yang mendasar sampai ke akar persoalan, memberikan tujuan dan proses yang beriorentasi ajaran Islam. ${ }^{1}$

Pemikiran pendidikan Islam, dari waktu ke waktu, mengalami perubahan seiring perubahan zaman dengan berbagai faktornya. Salah satu faktor yang mempengaruhi perubahan tersebut adalah perbedaan cara pandang dalam memaknai hakekat, tujuan, metode dan sumber pendidikan Islam. Secara historis, perubahan pemikiran pendidikan Islam selalu mengalami revolusi. Muhammad Jawwad Ridla mengatakan bahwa revolusi pemikiran pendidikan Islam terjadi pada masa sahabat Usman hingga abad IV hijriyah dengan ditandai semangat sejarahwan Muslim dan dinamika perkembangan pemikiran dalam berbagai dimensi. Lebih lanjut Ridla menganalisis sejarah perkembangan pemikiran tersebut ke dalam tiga tahap, yakni pertama, berawal dari hijrah Nabi SAW hingga berdirinya Dar al-Hikmah di Baghdad $(217 \mathrm{H} / 832 \mathrm{M})$; kedua, dari berdirinya Dar al-Hikmah hingga munculnya madrasah Nizamiyah di Baghdad (462 H/1065 M) dan ketiga, masa setelah era madrasah Nizamiyah hingga runtuhnya kekhalifahan Turki Usmani. ${ }^{2}$

Muhammad Jawwad Ridla ${ }^{3}$ menjelaskan pada tahap pertama pemikiran pendidikan Islam belum memunculkan teori pendidikan yang istimewa dan belum diformulasikan secara komprehensif. Tahap kedua merupakan fase perkembangan sumber sosial-filosofis pemikiran pendidikan Islam ditandai dengan gerakan pembentukan teori-teori pendidikan. Pada tahap ini muncul gerakan massif

${ }^{1}$ Omar Muhammad al-Toumy Al-Syaibani, Filsafat Pendidikan Islam, terj. Hasan Langgulung, 1979, (Jakarta: Bulan Bintang, 1979), hlm. 35.

${ }^{2}$ Muhammad Jawwad Ridla, Tiga Aliran Utama Teori Pendidikan Islam: Perspektif Sosiologis-Filosofis, Diterjemahkan oleh Mahmud Arif, (Yogyakarta: Tiara Wacana, 2002), hlm. 22.

${ }^{3}$ Ibid, hlm. 22-57. 
penerjemahan buku-buku filsafat Yunani, kedokteran, matematika dan disiplin ilmu lain ke dalam bahasa Arab (abad III dan IV M). Tahap ketiga, setelah runtuhnya dinasti Usmani, terjadilah padam pelita gerakan intelektual yang mengakibatkan pemikiran pendidikan Islam mengalami stagnasi. Dinamika perkembangan pemikiran pendidikan Islam tersebut mendorong para pemikir Muslim untuk mengkaji secara lebih mendalam agar melahirkan sebuah warisan pemikiran keislaman. Upaya tersebut, dari berbagai belahan dunia Islam, telah ditunjukkan dengan lahirnya tiga aliran utama pendidikan Islam, yaitu aliran agamis-konservatif, aliran religius-rasional dan aliran pragmatis-instrumental. ${ }^{4}$ Uraian ringkas dari ketiga aliran tersebut adalah: pertama, aliran agamis-konservatif yang cenderung bersikap murni keagamaan dalam kaitannya dengan persoalan pendidikan, artinya ilmu pengetahuan hanya terbatas pada pemaknaan dari sumber utama (Al-Qurean dan Sunnah). Tokoh-tokoh aliran ini adalah al-Ghazali, Nasiruddin al-Thusi, Ibnu Jamaeah, Sahnun, Ibnu Hajar al- Haitami dan alQabisi. Kedua, aliran religius-rasional meski tidak jauh dengan pemikiran kalangan "tradisionalis-tekstualis" mengatakan bahwa semua ilmu yang tidak menghantarkan pada tujuan akherat, maka akan menjadi bumerang bagi pemiliknya. Tokoh aliran ini adalah kelompok Ikhwan al-Shafa, al-Farabi, Ibnu Sina dan Ibnu Miskawaih. Menurut aliran ini. pendidikan ditafsirkan lebih luas sebagai aktivitas sosial (interaksi dalam kehidupan sosial) dan respons positif terhadap tuntutannya. Aliran ini juga mengaskan bahwa ilmu tidak semata berdasarkan teks namun dibutuhkan pemikiran yang rasional. Ketiga, aliran pragmatis-instrumental dengan tokoh satu-satunya adalah Ibnu Khaldun membagi ilmu pengetahuan berdasarkan tujuan fungsionalnya, bukan berdasar nilai substansialnya. Oleh karena itu pendidikan dipandang sebagai tujuan yang pragmatis dan berorientasi kepada aplikatif-praktis.

Pemetaan seperti di atas tentu berdasarkan pada konsep keilmuan yang berlandaskan aliran pendidikan Islam yang telah mereka pelajari. Menariknya, konsep keilmuan ternyata diakui sebagai tema sentra ataupun spektrum tradisi intelektual. Berdasarkan "peta" aliran itu, bahwa khazanah pemikiran pendidikan Islam tidaklah monolitik dan uniform, melainkan variatif dan plural seperti tradisi pemikiran plural lainnya. ${ }^{5}$

Muhaimin menambahkan dan mengembangkan tiga aliran utama yang

${ }^{4}$ Ibid, hlm. 74.

5 Mahmud Arif, dalam "Pengantar Penerjemah" Tiga Aliran Utama Teori Pendidikan Islam: Perspektif Sosiologis-Filosofis karya Muhammad Jawwad Ridla, (Yogyakarta: Tiara Wacana, 2002). hlm. x.

FaLASIFA, Vol. 10 Nomor 1 Maret 2019 | 155 


\section{Nafiur Rofiq}

telah disebutkan diatas dengan beberapa aliran yang lain, seperti: aliran PerenialEsensial Salafi, aliran Perenial Madzhabi, aliran Modernis, aliran Perenial-Esensialis Konstektual Falsifikatif dan aliran Rekonstruksi Sosial berlandaskan tauhid. Masingmasing mempunyai ciri-ciri pemikiran, yang berimplikasi pada fungsi pendidikan itu sendiri. ${ }^{6}$

Berdasarkan uraian di atas, tulisan ini mencoba mendeskripsikan tiga aliran utama pendidikan Islam dan teori-teori pembelajaran dalam Pendidikan Islam menurut Muhammad Jawwad Ridla tersebut serta implikasinya dalam praksis pendidikan Islam masa kini sekaligus harapannya di masa yang akan datang. Sedangkan lima aliran berikutnya yang ditulis Muhaimin sesungguhnya merupakan derivasi (turunan) yang telah dikembangkan lebih lanjut dari tiga aliran utama pendidikan Islam yang sudah digagas oleh Jawwad Ridla sebelumnya, oleh karenanya lima aliran berikutnya yang dikembangkan oleh Muhaimin tersebut diharapkan dapat melengkapi khazanah kajian ini.

\section{PEMBAHASAN}

\section{Tiga Aliran Utama Pendidikan Islam}

Sebelum munculnya klasifikasi terhadap tiga aliran utama pendidikan Islam oleh Muhammad Jawwad Ridla, terlebih dahulu telah diawali dengan adanya proses asimilasi antara pengaruh Islam dengan pengaruh Yunani yang kemudian merembes ke dalam lingkup Pendidikan Islam, dimana waktu itu dalam Islam masih belum terjadi konflik tajam di kalangan para ahli pendidikan Muslim karena memang belum ada pemikiran "ekstrim-fundamentalis" yang diderivasikan dari ajaran agama. ${ }^{7}$

Berikutnya setelah terjadi perselisihan dan pertentangan dalam lingkup kependidikan, maka timbullah hal yang pada satu sisi sangat penting dan pada sisi lain sangat mencemaskan, yaitu dalam lingkup pembagian ilmu atau kurikulum program pendidikan dan tujuan pendidikan secara umum. Dalam lingkup pendidikan tersebut mencuatlah polarisasi sedemikian rupa antar aliran-aliran pemikiran pendidikan Islam, yaitu polarisasi yang mengatasnamakan "baru" dan "klasik" dalam masyarakat Islam abad IV H, adalah sebuah masyarakat yang formatif dan dinamis. ${ }^{8}$ Dari sinilah tiga aliran utama dalam teori dan pemikiran pendidikan Islam dipetakan oleh Muhammad Jawwad Ridla.

${ }^{6}$ Muhaimin, Pengembangan Kurikulum Pendidikan Agama Islam di Sekolah, Madrasah, dan Pergumuan Tinggi, (Jakarta: PT. Raja Grafindo Persada, 2014), Cetakan ke6, hlm. 109-112.

${ }^{7}$ Muhammad Jawwad Ridla, Tiga Aliran Utama..., hlm. 74.

${ }^{8}$ Ibid. 


\section{Aliran Agamis Konserfatif (al-Diniy al-Mubafid)}

Tokoh-tokoh dalam aliran ini adalah Imam al Ghazali, Ibnu Hajar al Haitami, Ibnu Sahnun dan Nasirudin at Thusi. Aliran ini cenderung murni keagamaan dan aliran ini memaknai ilmu dengan makna yang sempit. Menurut at Thusi ilmu adalah yang berguna di hari ini dan akan membawa manfaat di akhirat kelak. ${ }^{9}$ Bila kita mau mengamalkan apa yang kita dapatkan dan terapkan maka inilah makna ilmu yang sebenarnya. Dimana ilmu dapat menjadi sarana agar menjadi orang yang lebih baik dan mau menjadikan orang lain untuk lebih baik, inilah ilmu yang sebenarnya.

Al-Gazali termasuk filosof pendidikan Islam berpaham empiris, yang menekankan pentingnya pendidikan terhadap pertumbuhan perkembangan anak didik. Menurutnya, seorang anak tergantung kepada kedua orang tuanya yag mendidiknya. Telah tertulis dalam hadist Nabi SAW:

قال رسول الله ص.م:" كلّ مولود يولد على الفطرة فأبواه يهوّدانه أو ينصرانه أو يمجّسـانه"

Tujuan pendidikan (jangka pendek) menurut al-Ghazali ialah diraihnya profesi manusia sesuai dengan bakat dan kemampuannya. (al-Ibrashi, 1990) syarat untuk mencapai tujuan ini, manusia harus memanfaatkan dan mengembangkan ilmu pengetahuan sesuai dengan bakatnya.

Al Ghazali mengklasifikasikan ilmu menjadi:

a. Berdasarkan pembidangannya, ilmu dibagi menjadi dua:

1) Ilmu Syar'iyah, ilmu yang berasal dari para Nabi, ${ }^{10}$ terdiri atas:

(a) Ilmu Ushul/ilmu pokok. Contoh: ilmu al Qur'an dan ilmu Hadis

(b) Ilmu Furu'/ilmu cabang. Contoh: ilmu Fiqh dan Akhlaq

(c) Ilmu Pengantar/muqoddimah. Contoh: ilmu Bahasa dan Gramatika

(d) Ilmu Pelengkap/mutammimah.

2) Ilmu Ghoiru Syar'iyah, ilmu yang berasal dari ijtihad 'ulama' dan intelektual muslim.

b. Berdasarkan sifatnya, ilmu dibagi menjadi dua yaitu:

1) Ilmu terpuji (mahmudah)

2) lmu tercela ( madzmumah).

Menurut Imam al Ghazali ilmu yang terpuji wajib dipelajari dan dipahami, sementara ilmu yang tercela wajib dihindari. Al-Ghazali juga berpendapat bahwa di dalam proses pendekatan pembelajaran, ada 2 macam yakni ta'lim insani dan

\footnotetext{
${ }^{9}$ Filsafat Pendidikan Islam/Silabus/aliran-utama-filsafat-pendidikan. html. 523

${ }^{10}$ Samsul Nizar, Filsafat Pendidikan Islam: Pendidikan Historis, Teoritis dan Praktis, (Jakarta: Ciputat Press, 2002), 90.
} 


\section{Nafiur Rofiq}

ta'lim rabbani. ${ }^{11}$ Ta'lim insani adalah belajar dengan bimbingan manusia. Pendekatan ini adalah cara umum yang biasanya dilakukan orang dan biasanya dilakukan dengan menggunakan alat-alat peraga inderawi yang diakui oleh orangorang berakal. Ta'lim insani dibagi menjadi 2:

a. Proses eksternal melalui proses belajar mengajar

Dalam proses belajar sebenarnya terjadi proses eksplorasi pengetahuan sehingga menghasilkan perubahan-perubahan perilaku. Seorang guru menyampaikan ilmu yang mereka miliki dan murid berusaha untuk menggali dan menggali dan mengerti apa yang ingin diketahui.

b. Proses internal melalui proses tafakkur

Tafakkur diartikan dengan membaca realitas dalam dimensi wawasan spiritual dan penguasaan pengetahuan hikmah. Proses tafakkur dilakukan dengan pembersihan jiwa terlebih dahulu dari segala sifat yang mengotori hati.

Al-Ghazali menegaskan bahwa ilmu-ilmu keagamaan hanya dapat diperoleh dengan kesempurnaan rasio dan kejernihan akal budi. Karena, hanya dengan rasiolah manusia mampu menerima amanat dari Allah dan mendekatkan diri kepada-Nya. Pemikiran al-Ghazali ini sejalan dengan aliran Mu'tazilah yang berpendapat bahwa rasio mampu menetapkan baik buruknya sesuatu.

Pola umum pemikiran Imam al Ghazali antara lain:

a. Kegiatan menuntut ilmu tiada lain berorientasi pada pencapaian ridha Allah;

b. Teori ilmu ilhami sebagai landasan teori pendidikannya, dan diperkuat dengan sepuluh kode etik peserta didik;

c. Tujuan agamawi merupakan tujuan puncak kegiatan menuntut ilmu;

d. Pembatasan term al-ilm hanya pada ilmu tentang Allah;

e. Belajar dengan niat ibadah dalam rangka taqarrub ila Allah, agar dapat mensucikan jiwa dengan akhlaq al-karimah ( Q.S.Al An'aam/6:162;Adz Dzariyat/ 51:56);

f. Belajar dengan bertahap dengan memulai pelajaran yang mudah ke sukar atau dari fardhu 'ain menuju fardhu kifayah ( Q.S.Al Fath/48:49)

Rumusan tujuan pendidikan aliran ini didasarkan pada firman Allah swt, tentang tujuan penciptaan manusia yaitu :

$$
\text { وَمَا خَلَقْتُ الْجِنَّ وَالِْنْسَ بِلَّ لِيَعْبُدُوْنِن }
$$

"Tidaklah Aku jadikan jin dan manusia melainkan agar beribadah kepada-Ku (Q.S. al-dzariat: 56).”

Sedangkan menurut Ibnu Jama'ah, para penuntut ilmu harus mengawali

${ }^{11}$ Baharuddin dan Esa Nur Wahyuni, Teori Belajar dan Pembelajaran, (Yogyakarta: Ar-Ruzz Media, 2010)

158 | FaLASIFA, Vol. 10 Nomor 1 Maret 2019 
belajarnya dengan al-Quran, menghafal dan menafsirkannya. Kemudian, ilmuilmu yang perlu diprioritaskan adalah Ulumul Quran, al-Hadits, Ulumul Hadits, Ushul, Nahwu dan Sharaf.

Implikasi aliran ini terhadap pendidikan, mengenai proses pembelajaran harus ada integrasi antara materi, metode dan media pendidikan. Seluruh komponen harus bisa dimaksimalkan pemakaiannya dalam pendidikan. Materi pengajaran yang diberikan harus sesuai dengan tingkat perkembangan anak, baik dalam hal usia, integrasi, maupun minat dan bakatnya. Jangan sampai anak diberi materi pengajaran yang justru merusak akidah dan akhlaknya.

Adapun metode pendidikan yang diklasifikasikan oleh al-Ghazali menjadi dua bagian: Pertama, metode khusus pendidikan agama, metode ini memiliki orientasi kepada pengetahuan aqidah karena pendidikan agama pada realitasnya lebih sukar dibandingkan dengan pendidikan umum lainnya. Kedua, metode khusus pendidikan akhlaq, al-Ghazali (1991) mengungkapkan:

"Sebagaimana dokter, jikalau memberikan pasiennya dengan satu macam obat saja, niscaya akan membunuh kebanyakan orang sakit, begitupun guru, jikalau menunjukkkan hanya satu jalan kepada murid, niscaya membinasakan hati mereka.

Adapun ilmu yang paling baik diberikan pada taraf pertama ialah agama dan syari'at, terutama al-Qur'an. Begitu pula metode/media yang diterapkan juga harus mendukung; baik secara psikologis, sosiologis, maupun pragmatis, bagi keberhasilan proses pengajaran. Pendidikan benar-benar ditujukan untuk mendekatkan diri kepada Allah, dunia bukanlah tujuan utama.

\section{Aliran Religius Rasional (al-Diny al-'Aqlaniy)}

Tokoh-tokoh aliran ini adalah Ikhwan al-Shafa, al-Farabi, Ibnu Sina, dan Ibnu Miskawaih. Aliran ini dijuluki "pemburu" hikmah Yunani di belahan dunia Timur, dikarenakan pergumulan intensifnya dengan rasionalitas Yunani. Menurut Ikhwan al-Shafa, ${ }^{12}$ yang dimaksud dengan ilmu adalah gambaran tentang sesuatu yang diketahui pada benak (jiwa) orang yang mengetahui. Proses pengajaran adalah usaha transformatif terhadap kesiapan ajar agar benar-benar menjadi riil, atau dengan kata lain, upaya transformatif terhadap jiwa pelajar yang semula berilmu (mengetahui) secara potensial, agar menjadi berilmu (mengetahui) secara riil-aktual. Dengan demikian, inti proses pendidikan adalah pada kiat transformasi

${ }^{12}$ Sebuah perkumpulan rahasia yang bergerak dalam lapangan ilmu pengetahuan dan asas utama perkumpulan ini adalah persaudaraan yang dilakukan dengan tulus ikhlas, kesetiakawanan yang suci dan murni, serta saling menasehati antara sesama anggota untuk menuju ridho Illahi dan tidak melalui jalan radikal-revolusioner.

FaLASIFA, Vol. 10 Nomor 1 Maret 2019 | 159 


\section{Nafiur Rofiq}

potensi-potensi manusia agar menjadi kemampuan "psikomotorik". ${ }^{13}$

Ikhwan berpendapat bahwa akal sempurna mengemanasikan keutamaankeutamaan pada jiwa dan dengan emanasi ini eternalitas akal menjadi penyebab keberadaan jiwa. Kesempurnaan akal menjadi penyebab keabadian jiwa dan supremasi akal menjadi penyebab kesempurnaan jiwa. ${ }^{14}$ Pandangan dualisme jiwaakal Ikhwan tersebut merupakan bukti dari pengaruh pemikiran Plato.

Menurut Ikhwan, jiwa berada pada posisi tengah antara dunia fisik-materiil dan dunia akal. Hal inilah yang menjadikan pengetahuan manusia menempuh laju “linier-progresif” melalui tiga cara, yaitu: (1) Dengan jalan indera, jiwa dapat mengetahui sesuatu yang lebih rendah dari substansi dirinya; (2) Dengan jalan burban (penalaran-pembuktian logis), jiwa bisa mengetahui sesuatu yang lebih tinggi darinya; dan (3) Dengan perenungan rasional, jiwa dapat mengetahui substansi dirinya. ${ }^{15}$

Dari hasil pembahasannya Ikhwan al Shafa menyusun sebuah buku yang terdiri dari sejumlah risalah yang berjudul "Rasail Ikhwan al Shafa wa al-Kullah alWafa". Kitab ini terdiri atas empat jilid yang berisikan ikhtisar tentang pengetahuan yang ada ketika itu yang mencakup semua objek studi manusia, seperti: ilmu pasti, ilmu alam, musik, etika, biologi, kimia, metodologi, gramatika, botani, metafisika, alam akhirat dan lain sebagainya.

Menurut Ikhwan, setiap anak lahir dengan membawa sejumlah bakat yang perlu diaktualisasikan dan pendidik seharusnya mengangkat potensi laten yang terdapat dalam anak tersebut. Di sini pendidik dan orang tua dituntut untuk memberikan contoh yang baik dalam perilaku sehari-harinya, sehingga menjadi panutan ke arah yang lebih baik.

Pada mulanya, jiwa manusia kosong. Setelah indera berfungsi, secara berproses manusia mulai menerima rangsangan dari alam sekitarnya. Semua rangsangan inderawi ini melimpah ke dalam jiwa. Proses ini pertama kali memasuki daya pikir (al-quwwah al-mufakkirat), kemudian diolah untuk selanjutnya disimpan ke dalam re-koleksi atau daya simpan (al-quwwah al-hafizhat) sehingga akhirnya sampai pada daya penuturan (al-quwwah al-nathiqat) untuk kemudian siap direproduksi.

Menurut Ikhwan al Safa, hakikat manusia terletak pada jiwanya. Sementara jasad merupakan penjara bagi jiwa. Oleh karena itu, ruang lingkup jasad hendaknya dipersempit, sedangkan ruang lingkup jiwa diperluas. Manusia

\footnotetext{
${ }^{13}$ Muhammad Jawwad Ridla, Tiga Aliran Utama..., hlm. 78.

${ }^{14}$ Ibid, hlm. 85-86.

${ }^{15}$ Muhammad Jawwad Ridla, Tiga Aliran Utama..., hlm. 87.
} 
hendaknya hidup zuhud agar jiwanya lebih leluasa atas tubuhnya. Kehidupan yang demikian akan mensucikan jiwanya dalam mengaharap cinta Allah. ${ }^{16}$

Teologi meliputi keyakinan atau akidah Ikhwan al-Shafa, persahabatan, keimanan, hukum Allah, kenabian, dakwah, ruhani, tatanegara, struktur alam, dan magis.Tujuan pendidikan menurut Ikhwan al-Shafa adalah untuk peningkatan harkat manusia kepada tingkatan yang tertinggi (malaikat yang suci), agar dapat meraih ridha Allah SWT.

Sedikit berbeda antara Ikhwan al Safa dan Ibnu Miskawaih, apabila Ikhwan al Shafa lebih terfokus kepada anak didik, Ibnu Miskawaih terkonsentrasi dengan suatu kedudukan ilmu dan budi pekerti. Menurut Busyairi Majidi (1997) Ibnu Miskawaih menempatkan ilmu ke dalam suatu kedudukan berdasarkan objek ilmu itu. Ilmu yang paling mulia menurutnya adalah ilmu pendidikan, karena objek kajiannya terletak pada budi pekerti manusia, menyangkut substansi manusia. ${ }^{17}$ Dan segala ilmu yang mengembangkan quwwatu al-nathiqoh adalah ilmu yang paling mulia.

Martabat suatu ilmu sesuai dengan urutan martabat hakikat objek ilmu itu dalam alam ini, misalnya ilmu tentang manusia lebih mulia dari ilmu hewan, dan ilmu hewan lebih mulia daripada ilmu tumbuh-tumbuhan, dan ilmu tumbuhan lebih mulai dari pada ilmu geologi, geologi (ilmu jamadat).

Konsep pendidikan Ibnu Miskawaih, sebagaimana yang tercermin dalam awal kitabnya Tabdzib al-Akblaq ialah terwujudnya pribadi susila. Khuluq adalah alamiah, namun bisa berubah cepat atau lambat. Pemikiran Miskawaih ini, menolak sebagain pemikiran Yunani bahwa karakter tidak bisa berubah karena ia berasal dari watak dan pembawaan. Miskawaih memberikan ilustrasi; bahwa anak yang dididik dengan suatu cara tertentu berbeda secara mencolok dalam menerima nilai-nilai akhlaq yang luhur.

Materi pendidikan, menurut Ibnu Miskawaih adalah hal-hal yang wajib bagi kebutuhan jasmani untuk membentuk akhlaq yang mulia yaitu materi yang berhubungan dengan ibadah fisik, seperti: sholat, puasa dan zakat. Dan hal-hal yang berhubungan dengan jiwa yaitu aqidah yang benar. Dan hal yang berhubungan dengan sesama manusia. Seperti; ilmu mu'amalat, pertanian dan perkawinan.

Sesungguhnya materi pendidikan yang dianut oleh Ibnu Miskawaih

\footnotetext{
${ }^{16}$ Yunasril Ali, Perkembangan Pemikiran Falsafi, hlm. 24.

17 Ahmad Syar'i, Filsafat Pendidikan Islam, (Jakarta: Pustaka Firdaus, 2005), hlm. 65.
} 


\section{Nafiur Rofiq}

dipengaruhi faham ontologism. ${ }^{18}$ Ibnu Miskawaih mengisyaratkan tiga metode pendidikan secara umum, yaitu keteladanan, latihan (riyadhah) dan tarqhib dan tarhib. Tarqhib artinya janji disertai bujukan dan rayuan untuk memotivasi beramal shaleh. Dan tarhib artinya ancaman melalui hukuman yang disebabkan perbuatan dosa, kesalahan atuapun perbuatan yang melanggar syari’at. Sedangkan latihan barangkali dipengaruhi oleh pemikiran sufistik.

Tokoh lain dari aliran ini adalah Al-Farabi. Ia menganalisis manusia secara "fungsional-organik". Ia membagi potensi manusia menjadi enam tingkatan:

a. Potensi al-ghadziyyah (organ-organ tubuh yang berguna untuk mencerna makanan). Potensi ini timbul setelah manusia lahir;

b. Potensi perasa, yaitu bisa merasakan hawa dingin atau panas, dan lain-lain;

c. Merespon dan bereaksi;

d. Potensi mutakhayyilah (imajinasi), yaitu mengasosiasikan dan memilah-milah unsur-unsur stimuli dengan aneka model;

e. Potensi muthlaqah (mengabstraksi), yaitu menalar, mengidentifikasi antara yang indah dan yang jelek, memungkinkan berkreasi dan berinovasi

Implikasi aliran ini terhadap pendidikan adalah ilmu pengetahuan tidak hanya sebagai sarana mendekatkan diri kepada Allah, tetapi juga sebagai saran untuk meningkatkan derajat manusia pada tingkatan yang tinggi, baik dalam lingkungan sosial maupun dalam pandangan agama. Pembentukan akhlaq dengan berlandaskan al-Qur'an dan al-Hadist,

Intisari daripada aliran religius rasional adalah tidak hanya mengedepankan agama, tetapi juga ilmu yang lainnya dianggap penting juga. Karena kita hidup di dunia dan akhirat.

\section{Aliran Pragmatis Instrumental (al-Dzarai'iy)}

Menurut Ibnu Khaldun, ilmu pengetahuan dan ilmu pembelajaran adalah pembawaan manusia karena adanya kesanggupan berfikir. Dalam proses belajar manusia harus sungguh-sungguh dan memiliki bakat. Dalam mencapai pengetahuan yang beraneka ragam, seseorang tidak hanya membutuhkan ketekunan, tapi juga bakat. Seseorang perlu mengembangkan keahliannya dibidang tertentu.

Ibnu Khaldun mengatakan bahwa: al-Ilm wa al-Ta'lim Thabi'iyyun fi al'Umran al-Basyari. (Khaldun, 1979). Pengetahuan dan pendidikan merupakan tuntutan alami dari peradaban (al-'Umran) manusia. Hal itu dimungkinkan karena manusia dibekali dengan akal, yang dengan akal itu manusia berpikir dan memiliki

${ }^{18}$ Ibid.

162 | FaLASIFA, Vol. 10 Nomor 1 Maret 2019 
motivasi untuk mengetahui sesuatu. Dengan berpikir berarti bersosialisasi dengan realitas di sekitarnya.

Ide tentang adanya hubungan antara ilmu dan peradaban memunculkan sesuatu ide yang lain yang merupakan konsekuensi logisnya yaitu: al-Ulum innama Takastsrat Haisu yaksuru al'Umran wa Ta'adzaa al-hadarah. Pengetahuan akan berkembang sesuai dengan perkembangan peradaban.

Ibnu Khaldun membagi ilmu pengetahuan menjadi tiga kelompok:

a. Ilmu lisan (bahasa), tata bahasa dan sastra;

b. Ilmu naqli, ilmu yang diambil dari al-Qur'an dan Hadits, berupa ilmu tafsir, sanad, serta istinbat tentang kaidah-kaidah fiqh;

c. Ilmu naqli, ilmu yang diambil dari al-Qur'an dan Hadits, berupa ilmu tafsir, sanad, serta istinbat tentang kaidah-kaidah fiqh.

Menurutnya ada tiga tingkatan tujuan yang hendak dicapai dalam proses pendidikan, yaitu:

a. Pengembangan kemahiran (al-malakah atau skill) dalam bidang tertentu. Orang awam bisa meneliti, pemahaman yang sama tentang suatu persoalan dengan seorang ilmuwan. Akan tetapi potensi al-malakah tidak bisa demikian oleh setiap orang, kecuali setelah ia benar-benar memahami dan mendalami suatu disiplin tertentu;

b. Penguasaan ketrampilan professional sesuai dengan tuntutan zaman (lingkungan dan materi). Dalam hal ini pendidikan hendaknya ditujukan untuk memperoleh ketrampilan yang tinggi pada potensi tertentu. Pendekatan ini akan menunjang kemajuan dan kontinuitas sebuah kebudayaan, serta peradaban umat manusia di muka bumi;

c. Pembinaan pemikiran yang baik. Kemampuan berpikir merupakan jenis pembeda antara manusia dengan binatang. Oleh karena itu, pendidikan hendaknya di format dan dilaksanakan dengan terlebih dahulu memperhatikan pertumbuhan dan perkembangan potensi-potensi psikologis peserta didik.

Implikasi aliran ini terhadap pendidikan adalah dalam pembelajaran, Ibnu Khaldun lebih memilih metode secara gradual sedikit demi sedikit, pertama-tama disampaikan permasalahan pokok tiap bab, lalu dijelaskan secara global dengan mempertimbangkan tingkat kecerdasan dan kesiapan anak didik, hingga selesai materi per-bab. Kedua, memilah-milah antara ilmu-ilmu yang mempunyai nilai instrinsik, semisal ilmu-ilmu keagamaan, kealaman, dan ketuhanan, dengan ilmuilmu yang instrumental, semisal ilmu-ilmu kebahasa-Araban, dan ilmu hitung yang dibutuhkan oleh ilmu keagamaan, serta logika yang dibutuhkan oleh filsafat. Pendidikan diupayakan agar peserta didik benar-benar menguasai suatu bidang ilmu pengetahuan yang memang telah menjadi bakatnya, yang nantinya dapat

FaLASIFA, Vol. 10 Nomor 1 Maret 2019 | 163 


\section{Nafiur Rofiq}

meningkatkan kehidupan sosialnya di masyarakat.

Menurut Ibnu Khaldun, orang yang mendapat keahlian dalam bidang tertentu jarang sekali ahli pada bidang lainnya, misalnya tukang jahit. Hal ini lantaran sekali seseorang menjadi ahli hingga keahliannya itu tertanam berurat akar di dalam jiwanya. Alasannya karena keahlian merupakan sifat atau corak jiwa yang tidak dapat tumbuh serempak. ${ }^{19}$

Dari deskripsi tiga aliran utama Pendidikan Islam tersebut di atas, maka dapat diikhtisarkan sebagaimana tabel berikut:

\begin{tabular}{|c|c|c|c|}
\hline $\begin{array}{l}\text { Tiga Aliran } \\
\text { Utama } \\
\text { Pendidikan } \\
\text { Islam }\end{array}$ & $\begin{array}{c}\text { Tokoh \& } \\
\text { Parameternya }\end{array}$ & $\begin{array}{c}\text { Tipologi/Ciri-ciri } \\
\text { Pemikirannya }\end{array}$ & $\begin{array}{l}\text { Fungsi } \\
\text { Pendidikan } \\
\text { Islam }\end{array}$ \\
\hline 1 & 2 & 3 & 4 \\
\hline $\begin{array}{l}\text { Aliran } \\
\text { Agamis- } \\
\text { Konservatif } \\
\text { (al-Diniy al- } \\
\text { Mubafid) }\end{array}$ & $\begin{array}{l}\text { - Tokohnya Imam al } \\
\text { Ghazali, Ibnu } \\
\text { Hajar al Haitami, } \\
\text { Ibnu Sahnun dan } \\
\text { Nasirudin at- } \\
\text { Thusi; } \\
\text { - Ilmu bersumber } \\
\text { dari al-Qur'an dan } \\
\text { al-Hadis. } \\
\text { Berdasarkan } \\
\text { pembidangannya, } \\
\text { ilmu dibagi dua: } \\
\text { 1. Ilmu Syar'iyah, } \\
\text { yang berasal dari } \\
\text { para Nabi, terdiri } \\
\text { atas: } \\
\text { - Ilmu Ushul/ilmu } \\
\text { pokok. Contoh: } \\
\text { ilmu al Qur'an } \\
\text { dan ilmu Hadis; } \\
\text { - Ilmu Furu'/ilmu } \\
\text { cabang. contoh: } \\
\text { ilmu Figh dan }\end{array}$ & $\begin{array}{l}\text { - Murni ilmu } \\
\text { keagama-an, } \\
\text { memaknai ilmu } \\
\text { secara sempit; } \\
\text { - Harus ada } \\
\text { integrasi antara } \\
\text { materi, metode } \\
\text { dan media } \\
\text { pendidikan; } \\
\text { - Mengutamakan } \\
\text { metode khusus } \\
\text { pendidikan } \\
\text { agama dan } \\
\text { metode khusus } \\
\text { pendidikan } \\
\text { akhlak }\end{array}$ & $\begin{array}{l}\text { - Pendidikan } \\
\text { benar-benar } \\
\text { ditujukan untuk } \\
\text { mendekatkan } \\
\text { diri kepada } \\
\text { Allah, dunia } \\
\text { bukanlah tujuan } \\
\text { utama. }\end{array}$ \\
\hline
\end{tabular}

${ }^{19}$ Abuddin Nata, 1997 
Aliran, Tipologi dan Teori Pendidikan Islam

\begin{tabular}{|c|c|c|c|}
\hline $\begin{array}{l}\text { Tiga Aliran } \\
\text { Utama } \\
\text { Pendidikan } \\
\text { Islam }\end{array}$ & $\begin{array}{c}\text { Tokoh \& } \\
\text { Parameternya }\end{array}$ & $\begin{array}{c}\text { Tipologi/Ciri-ciri } \\
\text { Pemikirannya }\end{array}$ & $\begin{array}{l}\text { Fungsi } \\
\text { Pendidikan } \\
\text { Islam }\end{array}$ \\
\hline \multirow[t]{2}{*}{1} & 2 & 3 & 4 \\
\hline & $\begin{array}{l}\text { Akhlaq; } \\
\text { - Ilmu Pengantar/ } \\
\text { muqoddimah. } \\
\text { Contoh: ilmu } \\
\text { Bahasa dan } \\
\text { Gramatika; } \\
\text { - Ilmu Pelengkap/ } \\
\text { mutammimah; } \\
\text { 2. Ilmu Ghoiru } \\
\text { Syar'iyah, ilmu } \\
\text { yang berasal dari } \\
\text { ijtihad 'ulama' dan } \\
\text { intelektual } \\
\text { muslim; } \\
\text { Berdasarkan sifatnya, } \\
\text { ilmu dibagi menjadi } \\
\text { dua yaitu: } \\
\text { 1.Ilmu terpuji } \\
\text { (mahmudah); } \\
\text { 2.lmu tercela } \\
\text { (madzmumah). }\end{array}$ & & \\
\hline $\begin{array}{l}\text { Aliran } \\
\text { Religius- } \\
\text { Rasional } \\
\text { (al-Diny al- } \\
\text { Aqlaniy) }\end{array}$ & $\begin{array}{l}\text { - Tokohnya: Ikhwan } \\
\text { al-Shafa, al-Farabi, } \\
\text { Ibnu Sina, dan } \\
\text { Ibnu Miskawaih; } \\
\text { - Ilmu bersumber } \\
\text { dari al-Qur’an dan } \\
\text { al-Hadis. } \\
\text { - Aliran ini dijuluki } \\
\text { "pemburu" hikmah } \\
\text { Yunani dikarena- }\end{array}$ & $\begin{array}{l}\text { - Inti proses } \\
\text { pendidikan } \\
\text { adalah } \\
\text { transformasi } \\
\text { potensi-potensi } \\
\text { manusia agar } \\
\text { menjadi } \\
\text { kemampuan } \\
\text { "psikomotorik } \\
\text { - Jiwa berada }\end{array}$ & $\begin{array}{l}\text { Tujuan pendidikan } \\
\text { untuk peningkatan } \\
\text { harkat manusia } \\
\text { kepada tingkatan } \\
\text { yang tertinggi } \\
\text { (malaikat yang } \\
\text { suci), agar dapat } \\
\text { meraih ridha Allah } \\
\text { SWT. }\end{array}$ \\
\hline
\end{tabular}

FalASIFA, Vol. 10 Nomor 1 Maret 2019 | 165 


\begin{tabular}{|c|c|c|c|}
\hline $\begin{array}{l}\text { Tiga Aliran } \\
\text { Utama } \\
\text { Pendidikan } \\
\text { Islam }\end{array}$ & $\begin{array}{c}\text { Tokoh \& } \\
\text { Parameternya }\end{array}$ & $\begin{array}{c}\text { Tipologi/Ciri-ciri } \\
\text { Pemikirannya }\end{array}$ & $\begin{array}{l}\text { Fungsi } \\
\text { Pendidikan } \\
\text { Islam }\end{array}$ \\
\hline \multirow[t]{2}{*}{1} & 2 & 3 & 4 \\
\hline & $\begin{array}{l}\text { kan pergumulan } \\
\text { intensifnya dengan } \\
\text { rasionalitas Yunani. }\end{array}$ & $\begin{array}{l}\text { pada posisi } \\
\text { tengah antara } \\
\text { dunia fisik- } \\
\text { materiil dan } \\
\text { dunia akal. } \\
\text { - "linier-progresif" }\end{array}$ & \\
\hline $\begin{array}{l}\text { Aliran } \\
\text { Pragmatis } \\
\text { Instrumenta } \\
1 \text { (al- } \\
\text { Dzaraii) }\end{array}$ & $\begin{array}{l}\text { - Tokohnya: Ibnu } \\
\text { Khaldun } \\
\text { - Ilmu bersumber } \\
\text { dari al-Qur'an dan } \\
\text { al-Hadis. } \\
\text { - Dalam proses } \\
\text { belajar manusia } \\
\text { harus sungguh- } \\
\text { sungguh dan } \\
\text { memiliki bakat; } \\
\text { - Dalam mencapai } \\
\text { pengetahuan yang } \\
\text { beraneka ragam, } \\
\text { seseorang tidak } \\
\text { hanya } \\
\text { membutuhkan } \\
\text { ketekunan, tapi } \\
\text { juga bakat. }\end{array}$ & $\begin{array}{l}\text { - Orang yang } \\
\text { mendapat } \\
\text { keahlian dalam } \\
\text { bidang tertentu } \\
\text { jarang sekali ahli } \\
\text { pada bidang } \\
\text { lainnya; } \\
\text { - Keahlian } \\
\text { merupakan sifat } \\
\text { atau corak jiwa } \\
\text { yang tidak dapat } \\
\text { tumbuh } \\
\text { serempak. }\end{array}$ & $\begin{array}{l}\text { - Pengembangan } \\
\text { kemahiran (al- } \\
\text { malakah atau skill) } \\
\text { dalam bidang ter- } \\
\text { tentu. } \\
\text { - Penguasaan } \\
\text { ketrampilan pro- } \\
\text { fessional sesuai } \\
\text { dengan tuntutan } \\
\text { zaman (lingkun- } \\
\text { gan dan materi). } \\
\text { - Pembinaan } \\
\text { pemikiran yang } \\
\text { baik. }\end{array}$ \\
\hline
\end{tabular}

\section{LIMA TIPOLOGI PEMIKIRAN PENDIDIKAN ISLAM}

Bertolak dari tiga aliran utama pendidikan Islam di atas, maka jika ditinjau dari segi karakteristik pemikirannya, aliran pendidikan Islam dapat di derivasi-kan menjadi lima macam ${ }^{20}$ tipologi pemikiran sebagai berikut:

${ }^{20}$ Muhaimin, Pengembangan Kurikulum Pendidikan Agama Islam di Sekolah, Madrasah, dan Pergumuan Tinggi, (Jakarta: PT. Raja Grafindo Persada, 2014), Cetakan ke6, hlm. 109-112. 


\section{Tipologi Perenial-Esensialis Salafi (tekstualis-salafi)}

Tipologi pemikiran ini bersumber dari al-Quran dan as-Sunnah, yang lebih menonjolkan wawasan Islam era salaf (berorientasi masa silam), sehingga lebih bersifat regresif-konservatif yakni mempertahankan dan melestarikan nilai-nilai era salafi. Aliran ini berupaya memahami ajaran dan nilai mendasar yang terkandung di dalam al-Qur'an dan Hadits Nabi dengan melepaskan diri, kurang begitu mempertimbangkan situasi konkrit dinamika pergumulan masyarakat muslim (era klasik maupun kontemporer) yang mengitarinya. Ciri-ciri pemikirannya adalah ia menjawab persoalan pendidikan dalam konsteks wacana salafi, memahami nash secara tekstual-lughawi, penafsiran ayat dengan ayat lain, ayat dengan hadis maupun hadis dengan hadis sehingga kurang adanya perkembangan dan elaborasi. Fungsi pendidikan Islam baginya adalah melestarikan budaya masyarakat salaf yang dianggap ideal serta mengembangkan potensi dan interaksinya dengan nilai dan budaya masyarakat era salaf.

\section{Tipologi Perenial-Esensialis Mazhabi (tradisionalis-madzbaby)}

Tipologi pemikiran ini bersumber dari al-Quran dan as-Sunnah, yang lebih menonjolkan wawasan kependidikan Islam yang tradisional dan cenderung untuk mengikuti aliran, pemahaman atau doktrin, serta pola-pola pemikiran sebelumnya atau pendahulunya yang dianggap sudah relatif mapan (establist) dan tepat atau sesuai. Aliran ini berupaya memahami ajaran, nilai mendasar yang terkandung dalam al-Qur'an dan Hadits melalui bantuan khazanah pemikiran Islam klasik, namun seringkali kurang begitu mempertimbangkan sosio-historis dan dinamika perkembangan zaman atau masyarakat setempat dimana mereka hidup di dalamnya. Ciri-ciri pemikiran dari aliran ini menekankan pada pemberian syarh dan basyiyah terhadap pemikiran pendahulunya, dan kurang adanya keberanian untuk mengkritik dan mengubah subtansi materi pendidikan pendahulunya.

\section{Tipologi Modernis}

Berbeda dengan kedua tipoologi di atas, tipologi pemikiran modernis lebih menonjolkan wawasan kependidikan Islam yang bebas modifikatif, progresif dan dinamis dalam menghadapi dan merespon tuntutan dan kebutuhan dari lingkungannya, dalam arti bagaimana pendidikan Islam mampu menyiapkan peserta didik yang mampu melakukan rekonstruksi pengalaman yang terus menerus, agar dapat berbuat sesuatu yang inteligen dan mampu melakukan penyesuaian kembali sesuai tuntutan dan kebutuhan lingkungan pada masa sekarang. Ciri-ciri pemikirannya adalah tidak terlalu berkepentingan (berlebihan) untuk mempertahankan dan melestarikan pemikiran dan sistem pendidikan para pendahulunya, lapang dada dan menerima pemikiran dari manapun dan siapapun dan selalu menyesuaikan perkembangan sosial dan iptek. Tugas pendidikan Islam adalah untuk 


\section{Nafiur Rofiq}

mengembangkan kemampuan peserta didik secara optimal, aliran ini hampir sama dengan aliran religius rasional yang diprakarsai oleh Ikhwan al Shafa. Sedangkan fungsi dari pada pendidikan Islam adalah sebagai berikut:

a. Upaya pengembangan potensi peserta didik secara optimal, baik potensi jasmani, akal maupun hati;

b. Upaya interaksi potensi dengan tuntutan dan kebutuhan lingkungannya;

c. Rekonstruksi pengalaman yang terus-menerus agar dapat berbuat sesuatu secara intelegen yang dilandasi dengan iman dan taqwa kepada Allah Swt.

\section{Tipologi Perenial-Esensialis Kontekstual-Falsifikatif (Neo-modernis)}

Tipologi pemikiran ini bersumber dari al-Quran dan as-sunnah, yang lebih mengambil jalan tengah antara kembali ke masa lalu dengan jalan melakukan kontekstualisasi serta uji falsifikasi dan mengembangkan wawasan-wawasan kependidikan Islam masa sekarang yang selaras dengan tuntutan perkembangan ilmu pengetahuan dan teknologi serta perubahan yang ada, wawasan kependidikan Islam yang concern terhadap kesinambungan pemikiran pendidikan Islam dalam merespon tuntutan perkembangan iptek dan perubahan sosial yang ada. Aliran ini berupaya memahami ajaran $\mathrm{Al}$ Qur'an dan nilai yang mendasar, terkandung di dalam Al Qur'an dan Hadits dengan mengikutsertakan, mempertimbangkan khazanah intelektual muslim klasik serta mencermati kesulitan-kesulitan dan kemudahan yang ditawarkan oleh dunia modern. Ciri-ciri aliran pendidikan ini sebagai berikut:

a. Menghargai pemikiran pendidikan Islam yang berkembang pada era salaf, klasik dan pertengahan;

b. Mendudukan pemikiran pendidikan Islam era salaf dan klasik serta pertengahan dalam konteks ruang dan zamannya untuk difalsifikasi;

c. Rekonstruksi pemikiran pendidikan Islam terdahulu yang di anggap kurang relevan dengan tuntutan dan kebutuhan era kontemporer.

Fungsi pendidikan Islam menurut aliran ini adalah sebagai:

a. Upaya pengembangan potensi secara optimal serta interaksinya dengan tuntutan dan kebutuhan lingkungan tanpa mengabaikan tradisi yang sudah mengakar;

b. Menumbuhkan nilai-nilai Ilahiyah dan insaniyah dalam konteks perkembangan Iptek dan perubahan sosial yang ada.

\section{Tipologi Rekonstruksi Sosial Berlandaskan Tauhid}

Tipologi pemikiran ini juga bersumber dari al-Quran dan as-sunnah yang progresif dan dinamis, lebih menonjolkan sikap yang proaktif dan antisipatif dalam menghadapi perkembangan Iptek, tuntutan perubahan, dan beriorentasi pada masa depan dan menuntut kreatifitas. Berangkat dari bottom-up yang diban- 
gun oleh grassroots, mengakui pluralisme, dan dalam konteks mengejar keunggulan. Tugas pendidikan Islam terutama membantu agar manusia menjadi makhluk yang cakap dan selanjutnya manusia mampu bertanggung jawab terhadap pengembangan masyarakat yang dilandasi iman dan taqwa kepada Allah. Karena hakikatnya manusia adalah khalifah Allah fil ardhi yang mampu untuk memecahkan permasalahan yang ada dengan potensi jismiah dan nafsiah yang mengandung dimensi al-nafsu, al-'aql dan al-qalb (temuan Baharuddin, 2001), sehingga ia siap mengaktualisasikan potensinya dalam konteks hubungan horisontal ( habl min al-nas), yang diwujudkan dalam bentuk rekonstruksi sosial secara berkelanjutan untuk mencapai ridho-Nya.

Fungsi pendidikan Islam adalah sebagai:

a. Upaya menumbuh-kembangkan kreativitas secara berkelanjutan;

b. Upaya memperkaya khazanah budaya manusia, dengan memperkaya isi nilainilai insani dan Ilahi;

c. Upaya menyiapkan tenaga kerja yang produktif yang berjiwa spirit Islam.

Dari deskripsi lima tipologi pemikiran Pendidikan Islam tersebut di atas, maka selanjutnya dapat diikhtisarkan sebagai berikut:

\begin{tabular}{|c|c|c|c|}
\hline $\begin{array}{l}\text { Aliran Pe- } \\
\text { renial- } \\
\text { Esensialis } \\
\text { Salafi } \\
\text { (tekstualis- } \\
\text { salafi) }\end{array}$ & $\begin{array}{l}\text { - Bersumber dari al- } \\
\text { Qurán dan Hadis } \\
\text { - Regresif ke masa } \\
\text { salaf } \\
\text { - Konservatif, mem- } \\
\text { pertahankan dan } \\
\text { melestarikan nilai- } \\
\text { nilai era salaf } \\
\text { - Wawasan kependi- } \\
\text { dikan Islam yang } \\
\text { berorientasi ke masa } \\
\text { silam (era salaf) }\end{array}$ & $\begin{array}{l}\text { - Menjawab persoalan } \\
\text { pendidikan Islam da- } \\
\text { lam konteks wacana } \\
\text { salafi; } \\
\text { - Memahami nash } \\
\text { dengan cara kembali } \\
\text { ke salafi secara teks- } \\
\text { tual; } \\
\text { - Memahami ayat den- } \\
\text { gan ayat lain, ayat } \\
\text { dengan hadis, hadis } \\
\text { dengan hadis dan ku- } \\
\text { rang adanya pen- } \\
\text { gembangan dan ela- } \\
\text { borasi }\end{array}$ & $\begin{array}{l}\text { - Melestarikan atau } \\
\text { memper- } \\
\text { tahankannilai dan } \\
\text { budaya masyara- } \\
\text { kat salaf karena ia } \\
\text { dipandang sebagai } \\
\text { masyarakat ideal } \\
\text { - Pengembangan } \\
\text { potensi dan in- } \\
\text { teraksinya dengan } \\
\text { nilai dan budaya } \\
\text { masyarakat era } \\
\text { salaf. }\end{array}$ \\
\hline $\begin{array}{l}\text { Aliran Pe- } \\
\text { renial- } \\
\text { Esensialis } \\
\text { Mazbabi } \\
\text { (tradisionalis- } \\
\text { madzhaby) }\end{array}$ & $\begin{array}{l}\text { - Bersumber dari al- } \\
\text { Qurán dan Hadis } \\
\text { - Regresif ke masa } \\
\text { pasca salaf/klasik } \\
\text { - Konservatif, mem- } \\
\text { pertahankan dan }\end{array}$ & $\begin{array}{l}\text { - Menekankan pada } \\
\text { pemberian syarb dan } \\
\text { hasyiyah terhadap } \\
\text { pemikiran pendahu- } \\
\text { lunya } \\
\text { - Kurang ada kebera- }\end{array}$ & $\begin{array}{l}\text { - Melestraikan dan } \\
\text { mempertahankan } \\
\text { nilai dan budaya } \\
\text { serta tradisi dari } \\
\text { satu generasi ke } \\
\text { generasi berikut- }\end{array}$ \\
\hline
\end{tabular}

FalASIFA, Vol. 10 Nomor 1 Maret 2019 | 169 


\begin{tabular}{|c|c|c|c|}
\hline & $\begin{array}{l}\text { melestarikan nilai- } \\
\text { nilai dan pemikiran } \\
\text { para pendahulunya } \\
\text { secara turun temu- } \\
\text { run; } \\
\text { - Mengikuti aliran, } \\
\text { pemahaman dan } \\
\text { pemikiran terdahu- } \\
\text { lu yang dianggap } \\
\text { mapan; } \\
\text { - Wawasan kependi- } \\
\text { dikan Islam yang } \\
\text { tradisional dan be- } \\
\text { rorientasi ke masa } \\
\text { silam }\end{array}$ & $\begin{array}{l}\text { nian untuk mengkri- } \\
\text { tisi atau mengubah } \\
\text { substansi materi pe- } \\
\text { mikiran para penda- } \\
\text { hulunya. }\end{array}$ & $\begin{array}{l}\text { nya; } \\
\text { - Pengembangan } \\
\text { potensi dan inte- } \\
\text { raksinya dengan } \\
\text { nilai dan budaya } \\
\text { masyarakat terda- } \\
\text { hulu. }\end{array}$ \\
\hline $\begin{array}{l}\text { Aliran Mod- } \\
\text { ernis }\end{array}$ & $\begin{array}{l}\text { - Bersumber dari al- } \\
\text { Qurán dan Hadis; } \\
\text { - Bebas modifikasi, } \\
\text { tapi terikat oleh ni- } \\
\text { lai-nilai kebenaran } \\
\text { universal (Allah); } \\
\text { - Progresif dan di- } \\
\text { namis dalam meng- } \\
\text { hadapi dan meres- } \\
\text { pons tuntutan dan } \\
\text { kebutuhan kebutu- } \\
\text { han lingkungannya; } \\
\text { - Wawasan kependi- } \\
\text { dikan Islam kon- } \\
\text { temporer }\end{array}$ & $\begin{array}{l}\text { - Tidak berkepenti- } \\
\text { ngan untuk memper- } \\
\text { tahankan dan meles- } \\
\text { tarikan pemikiran dan } \\
\text { system pondidikan } \\
\text { para pendahulunya } \\
\text { - Lapang dada dalam } \\
\text { menerima dan men- } \\
\text { dengarkan pemikiran } \\
\text { pendidikan dari ma- } \\
\text { napun dan siapapun } \\
\text { untuk kemajuan pen- } \\
\text { didikan Islam; } \\
\text { - Selalu menyesuaikan } \\
\text { dan melakukan pe- } \\
\text { nyesuaian kembali } \\
\text { pendidikan Islam } \\
\text { dengan tuntutan pe- } \\
\text { rubahan social dan } \\
\text { perkembangan Iptek. }\end{array}$ & $\begin{array}{l}\text { - Pengembangan } \\
\text { potensi individu } \\
\text { secara optimal; } \\
\text { - Interaksi potensi } \\
\text { dengan tuntutan } \\
\text { dan kebutuhan } \\
\text { lingkungannya; } \\
\text { - Rekonstruksi } \\
\text { pengalaman seca- } \\
\text { ra terus-menerus } \\
\text { agar dapat ber- } \\
\text { buat sesuatu yang } \\
\text { intelligent dan } \\
\text { mampu melaku- } \\
\text { kan penyesuaian } \\
\text { dan penyesuaian } \\
\text { kembali dengan } \\
\text { tuntutan dan ke- } \\
\text { butuhan lingkun- } \\
\text { gannya }\end{array}$ \\
\hline $\begin{array}{l}\text { Aliran Pe- } \\
\text { renial- } \\
\text { Esensialis } \\
\text { Kontekstual- } \\
\text { Falsifikatif } \\
\text { (Neo- }\end{array}$ & $\begin{array}{l}\text { - Bersumber dari al- } \\
\text { Qurán dan Hadis; } \\
\text { - Regresif dan kon- } \\
\text { servatif dengan me- } \\
\text { lakukan kontekstua- } \\
\text { lisasi dan uji falsifi- }\end{array}$ & $\begin{array}{l}\text { - Menghargai pemiki- } \\
\text { ran pendidikan Islam } \\
\text { yang berkembang } \\
\text { pada era salaf, klasik } \\
\text { dan abad pertenga- } \\
\text { han; }\end{array}$ & $\begin{array}{l}\text { - Pengembangan } \\
\text { potensi; } \\
\text { - Interaksi potensi } \\
\text { dengan tuntutan } \\
\text { dan kebutuhan } \\
\text { lingkungannya; }\end{array}$ \\
\hline
\end{tabular}

170 | FaLASIFA, Vol. 10 Nomor 1 Maret 2019 
Aliran, Tipologi dan Teori Pendidikan Islam

\begin{tabular}{|c|c|c|c|}
\hline modernis) & $\begin{array}{l}\text { kasi; } \\
\text { - Rekonstruktif yang } \\
\text { kurang radikal; } \\
\text { - Wawasan kependi- } \\
\text { dikan Islam yang } \\
\text { concern terhadap ke- } \\
\text { sinambungan pe- } \\
\text { mikiran pendidikan } \\
\text { Islam dalam meres- } \\
\text { pon tuntutan per- } \\
\text { kembangan Iptek } \\
\text { dan perubahan so- } \\
\text { sial kultural yang } \\
\text { ada. }\end{array}$ & $\begin{array}{l}\text { - Mendudukkan pemi- } \\
\text { kiran pendidikan Is- } \\
\text { lam era salaf, klasik } \\
\text { dan abad pertenga- } \\
\text { han dalam konteks } \\
\text { ruang dan zamannya } \\
\text { untuk difalsifikasi; } \\
\text { - Rekonstruksi pemiki- } \\
\text { ran pendidikan Islam } \\
\text { terdahulu yang di- } \\
\text { anggap kurang rele- } \\
\text { van dengan tuntutan } \\
\text { dan kebutuhan era } \\
\text { kontemporer. }\end{array}$ & $\begin{array}{l}\text { - Melstarikan nilai- } \\
\text { nilai ilahiyah dan } \\
\text { insaniyah sekali- } \\
\text { gus menumbuh- } \\
\text { kem-bangkan da- } \\
\text { lam konteks per- } \\
\text { kembangan Iptek } \\
\text { dan perubahan } \\
\text { sosial-kultural } \\
\text { yang ada. }\end{array}$ \\
\hline $\begin{array}{l}\text { Aliran Re- } \\
\text { konstruksi } \\
\text { Sosial } \\
\text { Berlandaskan } \\
\text { Tauhid }\end{array}$ & $\begin{array}{l}\text { - Bersumber dari al- } \\
\text { Qur'an dan Hadis; } \\
\text { - Progresif dan } \\
\text { dinamis; } \\
\text { - Rekonstruksi sosial } \\
\text { berkelanjutan yang } \\
\text { dibangun dari } \\
\text { bottom-up, } \\
\text { grassroot dan } \\
\text { pluralisme; } \\
\text { - Wawasan } \\
\text { kependidikan Islam } \\
\text { yang pro-aktif dan } \\
\text { antisipatif dalam } \\
\text { menghadapi } \\
\text { percepatan } \\
\text { perkembangan } \\
\text { Iptek, tuntutan } \\
\text { perubahan yang tak } \\
\text { terduga dan } \\
\text { eksponensial, dan } \\
\text { berorientasi ke masa } \\
\text { depan }\end{array}$ & $\begin{array}{l}\text { - Tidak menampilkan } \\
\text { konstruk tertentu } \\
\text { yang closed-ended } \\
\text { tetapi konstruk yang } \\
\text { terus dikembangkan } \\
\text { bolak-balik antara } \\
\text { empiri dan konsep } \\
\text { teori; } \\
\text { - Rekonstruksi sosial } \\
\text { dikembangkan post- } \\
\text { paradigmatic atau } \\
\text { paradigmanya terus } \\
\text { dikembangkan; } \\
\text { - Komitmen terhadap } \\
\text { pengembangan } \\
\text { kreativitas yang } \\
\text { berkelanjutan; } \\
\text { - Dalam menghadapi } \\
\text { keragaman budaya, } \\
\text { moral hidup } \\
\text { ditampilkan dalam a } \\
\text { fair justice dan } \\
\text { mampu membuat } \\
\text { overlapping concensus } \\
\text { tata nilai }\end{array}$ & $\begin{array}{l}\text { - Menumbuhkan } \\
\text { kreativitas peserta } \\
\text { didik secara } \\
\text { berkelanjutan; } \\
\text { - Memperkaya } \\
\text { khazanah budaya } \\
\text { manusia, } \\
\text { memperkaya isi } \\
\text { nilai-nilai insani } \\
\text { dan ilahi; } \\
\text { - Menyiapkan } \\
\text { tenaga kerja } \\
\text { produktif serta } \\
\text { mengantisipasi } \\
\text { masa depan atau } \\
\text { memberi corak } \\
\text { struktur kerja } \\
\text { masa depan; } \\
\text { - Ketiga fungsi } \\
\text { tersebut intinya } \\
\text { untuk } \\
\text { mengembangkan } \\
\text { manusia agar } \\
\text { menjadi cakap } \\
\text { atau kreatif untuk } \\
\text { selanjutnya } \\
\text { mampu }\end{array}$ \\
\hline
\end{tabular}

FalASIFA, Vol. 10 Nomor 1 Maret 2019 | 171 


\begin{tabular}{|l|l|l|l|}
\hline & & & bertanggungjawa \\
& & & $\begin{array}{l}\text { b terhadap } \\
\text { pengembangan } \\
\text { masyarakatnya. }\end{array}$ \\
\hline
\end{tabular}

\section{TEORI PENDIDIKAN ISLAM}

Secara komprehensif dan saling melengkapi, teori Pendidikan Islam yang bersumber dari kalangan ahli pendidikan Muslim tidak akan dapat ditemukan. Secara "induktif", hanya ditemukan teori-teori yang mirip yang tersebar dalam ragam karya tulis dan risalah para ahli. Menurut Muhammad Jawwad Ridla, ${ }^{21}$ terdapat dua faktor utama penyebab tidak adanya teori pendidikan Islam secara komprehensif, diantaranya:

\section{Terjadinya polarirasi antar pemikiran pendidikan Islam}

Polarisasi pemikiran pendidikan yang terjadi dalam hal ini adalah antar pemikiran yang bersifat rasional-filosofis dengan yang bersifat agamis-murni. Bila dicermati risalah-risalah pendidikan yang ditulis oleh al-Ghazali, al-Qabisi, Ibnu Sahnun, Ibnu Jama'ah, Ibnu Hajar al-Haitami dan Nashiruddin al-Thusi, maka akan tampak orientasi murni keagamaan dalam pendidikan mereka. Dari sini, pendidikan bagi mereka mengandung pengertian $t a^{\prime} d i b$ (moralisasi).

Al-Thusi menamakan risalahnya Adab al-Muta'allimin, Ibnu Jama'ah menyebut risalahnya al-Sami' wa al-Mutakallim fi 'Adabi al-'Alim wa alMuta'allim, Ibnu Hajar al-Haitami menyebut risalahnya dengan Tabrir alMaqal fi Adab wa Abkam wa Fawa'id Ma Yabtajj ilaiba Mu'addib al-Athfal, dan Sahnun memberi nama risalahnya Adab al-Mu'allimin. Sementara itu, risalah al-Qabisi diberi nama al-Risalah al-Mufashshalah li Abwal al-Muta'allimin wa Ahkam al-Muta'allimin wa al-Mu'allimin.

Dari segi penamaan risalah atau kitab-kitab para pemikir pendidikan Islam tersebut di atas, maka jelaslah bahwa al-Adab dan al-Ta'dib merefleksikan harapan-harapan masyarakat terhadap anak dan remaja agar bersedia menghormati institusi dan pranata sosial yang ada dan pola pemikiran umum yang berkembang. Para ahli pendidikan tersebut memiliki kecenderungan kuat "moralisasi" hingga menyedot sebagian besar perhatiannya terhadap hal-hal sepele yang membuat kita heran, misalnya perihal tata cara duduk di hadapan guru, berdiri tegak dengan dua tangan di atas dada di hadapan orang sepuh, melarang anak kecil berbicara di dekat orang yang sudah tua dan mencegah mereka agar tidak membantah omongan orang tua, dan seterusnya.

\footnotetext{
${ }^{21}$ Muhammad Jawwad Ridla, Tiga Aliran Utama..., hlm. 197-199.
} 


\section{Adanya pembatasan risalah pendidikan Islam hanya}

\section{untuk penuntut ilmu/subjek didik tingkat lanjut saja}

Dalam faktanya, tak dapat dipungkiri bahwa sebagian besar risalahrisalah pendidikan Islam hanya diorientasikan untuk penuntut ilmu/subjek didik tingkat lanjut saja. Risalah Ayyuh al-Walad karya Al-Ghazali misalnya, hanya ditujukan dan diperuntukkan pelajar tingkat lanjut dari murid-murid beliau, dimana tradisi ini juga diwarisi oleh pesantren salaf hingga saat ini. Risalah Ibnu Jama'ah tiada lain adalah tanggapan serangkaian persoalan seputar fiqih yang diajukan kepadanya oleh para praktisi hukum Islam. Demikian juga risalah-risalah al-Qabisi, al-Thusi dan Ibnu Sahnun. Tampaknya hanya karya Ikhwan al-Shafa dan Ibnu Khaldun yang berorientasi pada pendidikan dalam pengertian seperti yang kita pahami sekarang ini. Dalam pemikiran keduanya itu, secara signifikan tercetus "rekonsiliasi" antara dimensi rasional, psikologis, moral-etik dan sosiologis bagi keilmuan pendidikan.

Dari uraian kedua faktor penyebab tidak komprehensifnya pendidikan Islam tersebut di atas, maka yang dapat dilakukan dalam merumuskan konsep atau teori pendidikan Islam, hanyalah memetik serangkaian prinsip-prinsip utama pendidikan yang tersebar dalam beberapa risalah dan karya tulis mereka, lalu menatanya dalam konstruksi yang utuh, sehingga membentuk teori pendidikan yang komprehensif sebagai berikut:

\section{a. Konsep Pengajaran atau Pembelajaran}

Para ahli pendidikan Muslim menyadari sepenuhnya bahwa pengajaran/pembelajaran merupakan hal yang sangat unik dan kompleks, sebagaimana profesi-profesi lain, yang menuntut dimilikinya persyaratanpersyaratan tertentu oleh orang yang menekuninya. Ibnu Abdun berkata, "sesunguhnya pengajaran itu merupakan profesi yang membutuhkan pengetahuan, keterampilan dan kecermatan, karena ia sama halnya dengan pelatihan percakapan yang memerlukan kiat,strategi dan ketelatenan, sehingga menjadi cakap dan professional". ${ }^{22}$ Senada dengan hal itu, Ibnu Khaldun dalam al-muqaddimah menegaskan:

"Di antara hal yang menunjukkan bahwa pengajarsn itu merupakan "profesi"... adalah terjadinya keragaman istilah penyabutan. Tiap-tiap maha guru (para imam) mempunyai istilah sendiri bagi pengajaranya. Ini berarti istilah dimaksud bukanlah termasuk keilmuan; swbab, jika termasuk keilmuan, tentunya akan seragam.kesungguhan mengikuti forum-forum ilmiah, banyak menghafal dan tekun menuntut ilmu tidaklah mesti

\footnotetext{
${ }^{22}$ Ahmad al-syalabi, tarikh al-tarbiyah al-islamiyah, cet. II, (Kairo, tnp, 1961), hlm.
} 174.

FalASIFA, Vol. 10 Nomor 1 Maret 2019 | 173 


\section{Nafiur Rofiq}

menghasilkan kecakapandan kepakaran dalam keilmuan dan pengajaran. Salah satu hal yang melekat pada ilmu adalah kecerdasan dalam berucap dan diskusi dan tindakan nyata untuk memiliki kecakapan adalah kecakapan pengajaran".

Bermula dari perspektif profesionalitas-teknikalis, para ahli pendidikan muslim membedakan secara tegas antara pendidikan (altarbiyah) dan pengajaran (al-ta'lim). Menurut mereka, yang pertama ruang lingkupnya lebih luas dibanding yang kedua. Maka dari itu, al-Ghazali menasihati orang-orang yang bertanggung-jawab atas anak-anak agar menyadari sepenuhnya;

"Pendidikan anak tidak hanya tebatas pada pengajaran semata. Si penangung jawab berkewajiban mengawasi dari hal sekecil dan sedini mungkin. Ia jangan sampai menyerahkan anak yang berbeda di bawah tanggung jawabnya untuk diasuh dan disusui kecuali oleh perempuan yang baik, agamis dan hanya memakan sesuatu yang halal. Seyogyanya, secara cermat mengawasi anak semenjak dini, menumbuh kembangkan rasa malu pada diri anak, dan mengarahkan agar tidak berlebih-lebihan dalam makan dan minum". Al-Ghazali lebih jelas menambahkan, "pendidikan itu mirip seperti pekerjaan seorang petani yang menyiangi duri dari rerumputan agar tanamanya bisa tumbuh dan berkembang dengan baik.” 23

Keseriusan menangani urusan anak membawa para ahli pendidikan pada kesadaran bahwa aktivitas pendidikan dimulai dari semenjak awal kehidupan. Dalam risalah politiknya, Ibnu Sina mengatakan, "Sudah menjadi kewajiban orang tua memberi nama yang baik untuk anaknya dan memilih sang perempuan yang akan menyusui dan mengasuhnya. Jangan sampai berupa perempuan yang lemah akal dan liar atau perempuan yang mengidap jenis penyakit yang menular". Bila anak telah disapih, mulailah dari pendidikan moral dan pembentukan akhlaq, sebelum ia terlanjur mencerap moral tercela dan perangai hina. Sebab, anak akan gampang dengan segera menerima moral jelek dan rangsangan-rangsangan yang buruk dari luar. Bila ia terus menerus menerima rangsangan buruk, maka akan sulit baginya lepas dari perangai jelek. Oleh karena itu, seharusnya pendidik menjauhkan anak dari moral buruk. Kecenderungan mereka memahami kenyataan yang sebenarnya dari proses pengajaran, mengarahkan pada perenungan tentang peran bahasa dalam proses ini dan menyadarkan pada mereka akan arti penting bahasa sebagai instrumen utama pendidikan, karena bahasa menstranmisikan kata-kata yang

\footnotetext{
${ }^{23}$ Pernyataan al-Ghazali ini dikutip dari ibya' ulum al-Din dan Ayyuba al-Walad.
} 
mengandung arti ke rasio subjek didik yang terkadang menyusahkan proses belajar. Ibnu Khaldun menganggap bahasa sama halnya dengan "tirai” yang menutupi realitas kebenaran dari rasio dan menuntut subjek didik agar serius berusaha malampaui ide-ide pemikiran (fanatisme ide) sebelum tekun konsentrasi belajar. Ibnu Khaldun mengingatkan para subjek didik dan guru terhadap empat hal yang mencirikan kata-kata, yaitu:

1) Relasi makna antara bahasa tulis dengan bahasa lisan/ucap;

2) Relasi makna antara bahasa ucap dengan arti yang dikehendaki;

3) Tata aturan dalam susunan makna untuk bias menunjukkan maksud tertentu berangkat dari strukltur baku sebagaimana pada tata logika;

4) Makna-makna "substansif" yang dihasilkan dari relasi "dalam" struktur bahasa. $^{24}$

Secara umum, patut kita cermati bahwasanya pergumulan intens dengan profesi pengajaran, telah mengantarkan para pemikir Muslim pada penolakan warisan sebagai prinsip dasar pembelajaran, sebaliknya pandangan kesiapan belajarlan yang menjadi prinsip dasar pembelajaran. Ibnu Miskawih mengatakan, "Akhlak manusia sama sekali bukan hal alamiah, dan juga bukan tidak alamiah. Sebab, pada dasarnya secara alamiah kita menerima akhlak, namun ia bias dibentuk dengan ta'dib (moralisasi), baik cepat atau lambat. Inilah pendapat yang saya anggap benar, karena sudah saya buktikan secara empiris. $" 25$

\section{b. Dasar-dasar Psokologis Aktivitas Belajar}

Berangkat dari kajian konsep pengajaran, terdapat beberapa dasar psikologis pendidikan yang sangat penting yang bisa diambil dari pemikiran para ahli pendidikan Muslim, hal pertama kali yang mereka sadari, bahwa al-idrak (kognisi) adalah dasar utama pembelajaran. Al-Thusi berkata; "Seorang subjek didik tidak bisa memperoleh sesuatu yang tidak ia pahami. Karena itu, mengharuskan si subjek didik agar mengawali aktivitas belajar dari hal yang paling dekat dengan pemahamannya. Dan hendaknya juga guru membatasi diri mengajarkan materi yang sesuai dengan kadar pemahaman subjek didiknya. Ia tidak boleh mengajarkan materi di luar kemampuan nalar subjek didik, sehingga bisa menjadikannya putus asa atau semakin bebal.”

Al-Ghazali dalam Ihya' mengatakan 'Sekiranya subjek didik bersusah-

${ }^{24}$ Ibnu Khaldun, al-Muqaddimah, jilid I, Ali Abdul Wahid Wafi (ed.), (Kairo: Nasyr Lajnati al-Bayan al-Arabi, 1960), hlm. 535.

${ }^{25}$ Ibnu Miskawaih, Tahdzib al-Akblaq wa Tathhir al-A'raq, Beirut: tnp., 1961 dalam Muhammad Jawwad Ridla, Tiga Aliran Utama..., hlm. 202.

FaLASIFA, Vol. 10 Nomor 1 Maret 2019 | 175 
M. Nafiur Rofiq

payah untuk memperoleh ilmu dengan usaha yang melebihi kemampuan dirinya dan (bahkan) sang guru sendiri pun merasa khawatir untuk melarangnya, hendaklah ia berpesan agar subjek didik peduli terhadap dirinya sendiri”, kata Ibnu Jama'ah dalam Tadzkirat al-Sami. Para ahli pendidikan Muslim mengharuskan guru untuk memberi perlakuan yang berbeda terhadap subjek didik yang cerdas dengan subjek didik yang berkemampuan terbatas. Guru mengajarkan materi yang jelas dan sederhana, agar dapat dipahami oleh subjek didik yang berkemampuan terbatas ini; jangan sampai guru menyampaikan kepadanya materi yang rumit dan kompleks, sebab hal ini dapat menyurutkan minat dan animonya untuk belajar.

Bukti kesadaran para ahli pendidikan Muslim akan adanya hubungan erat antgara potrensi-potensi intelektual subjek didik dengan materi keilmuan yang diajarkan kepadanya, Ibnu Jamaáh mengingatkan para guru mengenai keharusan mereka membeberkanb dan memerinci materi yang disampaikan, sehingga mudah dipahami oleh para subjek didik, dan ini merupakan keteladanan yang telah ditunjukkan Nabi; "Pembicaraannya begitu terperinci dan gambling, sehingga yang mendengar mudah memahaminya. Sewaktu mengucapkan kata-kata penting, diulangnya tiga kali agar dipahami, dan di saat rampung membicarakan suatu persoalan, beliau berhenti sejenak memberi kesempatan orang lain bertanya atau berbicara”, demikian kata Ibnu Jamaáh dalam Tadzkirat al-Sami'.

Berdasarkan hal itu, para ahli pendidikan Muslim melarang pencampuran ragam ilmu untuk diajarkan kepada subjek didik pemula, karena dikhawatirkan bias mengacaukan pikirannya. Ibnu Khaldun berkata, "Termasuk pola elok dan cara yang harus ditempuh dalam pengajaran adalah tidak dicampurnya dua (atau lebih) disiplin ilmu untuk diajarkan kepada subjek didik". Ia menuntut agar pengajaran ragam ilmu pengetahuan dilakukan secara bertahap, dari yang sederhana menuju hal yang kompleks seiring dengan taraf kematangan dan kesanggupan subjek didik dalam menguasainya. Apabila hal yang semestinya diajarkan pada tingkat lanjut, kemudian diajarkan pada tingkat awal, maka ia akan mengalami ketidaksanggupan dalam memahami dan jauh dari kesiapan diri untuk belajar, sehingga perolehan ilmu terasa amat sulit. Selanjutnya ia menjadi malas dan berpaling dari konsentrasi belajar. Dan hal ini akan berakibat pada jeleknya pengajaran". ${ }^{26}$ Termasuk prinsip dasar pendidikan, adalah penegasan para

${ }^{26}$ Ibnu Khaldun, al-Muqaddimah..., hlm. 533.

176 | FalAsifa, Vol. 10 Nomor 1 Maret 2019 
ahli pendidikan Muslim bahwa usia yang pantas untuk pengajaran awal adalah enam tahun. Ibnu Sina dalam al-Qannn berkata, "Jika usia anak telah mencapai enam tahun, maka ia sudah seharusnya dibawa kepada guru untuk belajar serius dan intensif'.

\section{c. Pemahaman tentang Subjek-Didik dan Kejiwaannya}

Para ahli pendidikan Muslim sejak awal menyadari sepenuhnya bahwa pemahaman tentang kejiwaan anak merupakan dasar pijakan bagi keberhasilan pengajaran. Ibnu Sina dalam al-Qanun menyatakan:

"Adalah sebuah keharusan, perhatian diarahkan pada pemeliharaan akhlak anak, yakni dengan menjaganya agar tidak mengalami luapan amarah, takut dan sedih. Caranya melalui perhatian seksama yang dilakukan anak atas perihal dirinya dan apa yang dibutuhkannya. Hal ini mempunyai dua kegunaan: kegunaan bagi jiwa anak dan kegunaan bagi badannya. Sebab, ia sejak dini tumbuh dengan (kebiasaan) akhlak mulia sesuai bahan makanan yang dikonsumsinya dan akhlak mulia ini dapat menjaga kesehatan jiwa dan badannya sekaligus". ${ }^{27}$

Berangkat dari tuntutan atas keharusan memahami perihal diri anak, para ahli pendidikan Muslim mempersyaratkan terlebih dahulu memahami lingkungan sosial anak, terutama lingkungan keluarganya. Disebutkan dalam kitab al-Irsyad wa al-Ta'lim ${ }^{28}$ Änak adalah cerminan kondisi keluarganya. Semua hal yang terjadi dalam keluarga, baik yang positif maupun yang negatif dan semua hal yang didengar dan dilihat, akan membentuk kepribadian anak. Karena itu, usaha serius sang Ibu merupakan hal terpenting dalam pendidikan anak. Barangsiapa hanya getol mengurusi harta-bendanya, lupa mengurusi anaknya,maka sama dengan tidak mempedulikan anak dan harta benda sekaligus.

Pendidikan keutamaan (nilai) tidak cukup diselenggarakan dalam sekolah, melainkan perlu ditanamkan pada diri anak semenjak ia mulai bisa berkomunikasi. Orang yang pertama kali dituntut menjalankan tugas ini tentunya adalah orang yang intens bergaul dengan anak, dan orang yang perilaku, ucapan dan perangainya turut mempengaruhi pribadi anak". Kemudian bila dikaitkan dengan hal-hal yang diperlukan oleh pendidikan, yaitu: perhatian, keseriusan, simpati dan empati, maka jelaslah pendidikan tidak akan sempurna hanya mengandalkan fitrah Ilahi yang ada pada anak.

\footnotetext{
${ }^{27}$ Ahmad Syalabi, Tarikh al-Tarbiyah al-Islamiyah..., hlm. 246.

${ }^{28}$ Kitab ini tidak diketahui pengarangnya yang berasal dari kelompok sufi; kitab ini ditemukan oleh Ahmad Syalabi di Perpustakaan Turki, dan kemudian dicuplik untuk dimasukkan ke dalam bukunya Tarikh al-Tarbiyah al-Islamiyah.
}

FaLASIFA, Vol. 10 Nomor 1 Maret 2019 | 177 


\section{Nafiur Rofiq}

Tidak dapat dipungkiri adanya pengaruh dari relasi personal dengan sesama pada diri anak, bahkan tata pergaluan relasi personal ini merupakan sumber utama yang mempengaruhi pertumbuhan dan perkembangan kejiwaan dan moral anak. Karena itu, para ahli pendidikan Muslim menuntut perlunya anak mempunyai peer-group yang baik di tempat pembelajarannya, mengingat dari sini ia akan banyak menyerap pelajaran dan mendapatkan rangsangan afektif-positif.

Dalam hal pemberian sanksi edukatif, Ibnu Jamaah membuat urutan sanksi edukatif ke dalam empat tingkat yang dikenakan pada subjek didik (anak) dikala is melakukan hal yang tidak pantas, berupa melakukan perbuatan yang diharamkan, dimakruhkan, hal yang mengakibatkan kerusakan (dampak negative) atau hal yang mengakibatkan pengabaian tugas, tidak sopan terhadap guru, banyak bicara, salah bergaul dan lain sebagainya. Langkah-langkah guru dalam memberikan sanksi edukatif adalah sebagai berikut:

1) Menunjukkan sikap melarang di hadapan anak yang bersangkutan, tanpa menunjuk hidung;

2) Jika si anak masih belum berhenti, guru melarangnya secara personal;

3) Jika anak itu masih juga belum berhenti, guru melarangnya dengan tegas dan teguran keras dihadapan anak-anak yang lain;

4) Jika anak itu masih saja belum berhenti, maka guru boleh menghukum dan mengucilkannya, agar jera dan tidak sampai mengganggu temannya yang lain [Ibnu Jamaáh dalam Tadzkirat al-Sami'].

\section{d. Metode Pengajaran atau Pembelajaran}

Para ahli pendidikan muslim sangat memperhatikan persoalan metode pengajaran dan menganggapnya sebagai hal strategisbagi keberhasilan proses pembelajaran. Kita dapat menemukan bukti perhatian besar mereka dalam kritik yang dilontarkan oleh ibnu Khaldun terhadap metode pembelajaran yang digunakan pada masanya. Ibnu Khaldun berkata dalam al-muqaddimah:

"para guru dalam proses pembelajaran awal-kali mengajarkan materi materi yang sulit dan mengharuskan murid-muridnya untuk memecahkanya, mereka beranggapan bahwa hal demikian merupakan hal positif bagi pembelajaran.selain itu, mereka memadukannya dengan ragam disiplin lain yang kompleks, sementara murid-murid belum siap mencernanya. Padahal kesiapan dan kemampuan mencerna itu berkembang gradual. Murid pada awalnya hanya mampu memahami sebagian saja, melalui analogi dan contoh kongkrit,lalu kesiapan dan kemampuan mencerna berkembang 
sedikit demi sedikit seiring dengan pengulangan pengulangan”.

Dengan demikian terdapat beberapa poin penting yang bisa disimpulkan menyangkut metode efektif pengajaran yang diinginkan para ahli pendidikan Muslim, sebagai berikut:

1) Mereka menuntut guru untuk berusaha serius mungkin mendekatkan meteri pengetahuan yang diajarkan dengan pemahaman subjek didik seiring dengan perkembangan usianya, tingkat kematangan behasa dan kecerdasannya. Kemudian secara bertahap pengajaran berawal dari hal yang sederhana menuju hal yang kompleks, dari hal yang akrab dengan pengalaman subjek didik menuju hal yang asing darinya. Ibnu Jama'ah mengatakan "guru dituntut untuk berusaha serius mengajar subjek didik sesuai dengan tingkat pemahamannya, jangan sampai guru mengajarkan materi tidak proporsional dan tidak dapat dipahami subjek didiknya. Kslsu memsng perlu penjabaran, pengulangan dan pemberian contoh, maka ia harus bersedia melakukanya".

2) Untuk mencapai tujuan ini diperlukan tiga tahapan sistemik, yakni: a) guru menyampaikan problem inti dari setiap bab kajian dengan elaborasi yang bias dipahami oleh subjek didik, agar secara umum diperoleh gambaran utuh keseluruhan bab kajian b) kemudian setelah rampung akhir bab kajian, dilanjutkan ke bab kajian berikutnya secara bertahap dengan mengulas ragam variasi pendapat yang berkembang secara elaboratif-diskursif. c) guru menyelesaikan dan menjelaskan problem-problem pelik yang tak terpecahkan agar subjek didiknya bias mencapai penguasaan materi yang argumentatif [inilah yang diistilahkan oleh Ibnu Khaldun dengan al-Ta'lim al-Mufid].

3) Setelah solidasi tahap-tahap pemantapan dalam penguasaan dan pengembangan materi pembelajaran subjek didik, guru perlu menyusun strategi lanjut berupa diskusi, dialog-diskursif,aduargumentasi. Dengan strategi ini, materi pembelajaran yang telah dikuasai berubah menjadi sebuah "pengalaman" pribadi yang teruji. Sebab, "efek diskusi dan dialog diskursif itu jauh lebih kuat dibandingkan dari efek pengulangan "[kata al-Thusi].

Bukan hanya karena alasan efek pengembangan materi kajian yang menyebabkann strategi diskusi dan dialog-diskursif dinilai penting dalam pembelajaran, melainkan juga karena para ahli pendidikan Muslim menganggap strategi ini sangat efektif untuk pembentukan dan pembinaan kepribadian subjek didik, dan pembiasaan untuk bersikap objektif-kritis. Menurut al-Thusi, penuntut ilmu perlu diskusi dan berdialog-diskursif. Ia

FalASIFA, Vol. 10 Nomor 1 Maret 2019 | 179 


\section{Nafiur Rofiq}

seharusnya mempunyai keinsyafan (ketulusan mengakui kekurangan diri) dan kesediaan berefleksi, sehingga dapat mengndalikan diri dan tidak emosional. Sebab, diskusi dan dialog-diskursif pada dasarnya adalah musyawarah, dan musyawarah memerlukan hal tersebut. Diakui arti penting pengulangan dan penghafalan bagi pemantapan pengetahuan yang diperoleh, namun dalam rangka penggalian kebenaran, maka refleksi dan keinsyafan sangat diperlukan, bukan emosi dan kegaduhan. Menurut Ibnu Jama'ah;

"Sewaktu guru selesai menjelaskan materi pelajaran, patut kiranya ia mengajukan beberapa pertanyaan yang terkait kepada para peserta didiknya untuk mengetahui tingkat pemahaman dan penguasaan mereka. Jika didapati ada yang sudah tinggi tingkat pemahaman dan penguasaannya, guru perlu mengapresiasinya. Jika didapati ada yang masih belum menguasai dan memahami, guru bersedia melakukan remedi”.

Perlunya guru melontarkan pertanyaan terkait, mengingat peserta didik sering kali merasa malu jika berkata belum paham. Guru hendaknya menghindari bertanya kepada peserta didiknya: "Apakah kamu sudah paham?", kecuali bila ia merasa peserta didiknya tidak akan menjawab "Ya", padahal belum paham. Bila tidak demikian, guru perlu menghindari pola pertanyaan seperti itu.

\section{e. Konsep Guru/Pengajar}

Para ahli pendidikan Muslim menyadari bahwa proses pembelajaran itu merupakan proses interaksi rasional dan hidup antara pendidik dan peserta didik; antara orang yang sudah "dewasa" dan orang yang belum dewasa. Karena itu, mereka menetapkan dua prinsip dasar edukatif yang sangat penting. Pertama, kitab (buku) tidak bisa menggantikan posisi guru dalampengajaran. Mereka mengecam gejala pemosisian buku sebagai guru. Imam al-Syafi'i pernah mengatakan, "barang siapa menggeluti ilmu hanya berdasar pada lembaran-lembaran buku, maka ia berarti telah menyianyiakan banyak hal". ${ }^{29}$ Berpijak pada prinsip dasar ini, para ahli pendidikan Muslim mengakui urgensi peran guru dalam proses pembelajaran, Ikhwan al-Shafa mengatakan, "semua orang pada awalnya tidak mempunyai pengetahuan apa-apa, karena itu masing-masing membutuhkan guru (pembimbing) dalam proses belajar, pembinaan moral dan keyakinannya".

${ }^{29}$ Pendapat ini merupakan nasihat "baru" bagi kalangan yang terlalu mengagungagungkan gagasan semisal: teknologi pendidikan dan pengajaran terprogram dewasa ini. Mereka menilai bahwa efektifitasnya telah melampaui peran alat pendidikan "konvensional" (termasuk guru). 
Dengan mempercayakan tugas penting pendidikan generasi muda kepada sosok guru, maka banyak harapan dan persyaratan yang diberikan bagi seorang guru yang diamanati mengajar, yaitu kesempurnaan pribadi, baik dalam kapasitas keilmuan, moral maupun perangainya.

Ibnu Sina dalam risalah al-Siyasah mengatakan, "sepantasnya bila seorang pendidik itu cerdas, agamis, bermoral, simpatik, karismatik dan pandai membawa diri. Sebelum tampil di depan para murid hendaknya ia terlebih dulu tampak cerdas, bersih dan berkepribadian". Ikhwan al-Shafa menetapkan syarat: cerdas, bermoral, dan objektif, bagi guru. Dikatakan, "ketahuilah wahai saudaraku!, termasuk hal yang penting bagi kebahagiaan adalah mendapat guru yang cerdas, berwatak, bermoral, tulus-ikhlas, beretos keilmuan dan tidak fanatik buta”. Posisi guru bagi al-Ghazali, sedemikian tinggi menggantikan posisi Rasulullah dalam membimbing umat manusia, dimana Rasul adalah Guru pertama umat Islam. Karenanya, ia menetapkan persyaratan tertentu bagi guru, yaitu hendaknya guru jauh dari sifat rakus dunia dan gila kehormatan. Guru bersedia melatih dirinya untuk tidak banyak makan, tidak banyak bicara, tidak banyak tidur, memperbanyak shalat, bersedekah dan berpuasa. Guru menjadikan akhlak yang baik sebagai perangainya, diam dan kalem (tidak grusa-grusu). Jika persyaratan-persyaratan ini dipenuhi, maka sosok guru bersangkutan adalah cerminan pribadi Nabi yang patut diteladani [al-Ghazali dalam Ayyuh alWalad].

Dengan pandangan yang demikian tinggi terhadap sosok dan profesi guru, al-Ghazali meminta guru menyayangi peserta didik bagaikan anak kandung sendiri. Demikian halnya, al-Ghazali menuntut agar tidak ada perseteruan dan dendam diantara sesama guru, karena akan berdampak negatif pada diri peserta didik. Al-Ghazali berkata:

"Seorang guru yang ahli dalam suatu disiplin ilmu tertenti hendaknya tidak mencemooh disiplin ilmu lain, misalnya guru ilmu bahasa mencemooh disiplin ilmu fiqih, guru ilmu fiqih mencemooh disiplin ilmu Hadis dan Tafsir yang dinilainya hanya bersifat replikatif, tidak ada penalaran. Guru ilmu Kalam mencemooh disiplin ilmu fiqih yang dinilainya hanya sebagai ilmu cabang dan hanya berisi seputar "darah" perempuan, berbeda dengan ilmu kalam yang berbicara tentang sifat-sifat Tuhan. Tindakan-tindakan semacam ini merupakan akhlak tercela yang harus dijauhkan dari diri peserta didik" [Lihat, Ihya' Ulumuddin].

f. Penyiapan Individu yang mampu berperan dalam kegiatan Ekonomi Masyarakat.

Dalam kajian sebelumnya telah disinggung bahwasanya para ahli

FalASIFA, Vol. 10 Nomor 1 Maret 2019 | 181 
M. Nafiur Rofiq

pendidikan dari aliran Rasionalis menganggap persoalan "sosialkemasyarakatan" merupakan kebutuhan asasi manusia. Mereka mengaitkan antara keutamaan dengan kerjasama dan partisipasi aktif dalam kehidupan bersama. Menurut mereka, keutamaan hanya dicapai melalui amalperbuatan yang mewujud pada kerjasama dan partisipasi aktif dalam interaksi sosial. Karena itu, Ibnu Miskawaih mengecam pendapat kalangan yang mengatakan bahwa keutamaan itu ditemukan pada sikap zuhud dan menjauh dari kehidupan bersama (eskapis-isolasionis), entah dengan cara menyendiri di tempat sunyi dan sepi, berdiam diri di ruangan khusus yang terpencil atau berkelana kesana-kemari. Ia berkata, "Orang-orang seperti itu tidak akan mendapatkan keutamaan kemanusiaan sedikitpun”. Sebab, orang yang tidak pernah bergaul dengan sesama dan hidup bermasyarakat, tidak akan muncul sifat iffah (pandai menjaga diri), dermawan dan adil. Bahkan potensi-potensi yang dimilikinya akan-sia-sia, tidak ada aktualisasi positif dan negatifnya dan tidak ubahnya seperti benda mati atau orang mati. ${ }^{30}$

Adanya pergumulan praktis dengan kehidupan melahirkan konklusiedukatif yang sangat penting dalam pemikiran para ahli pendidikan Muslim, yaitu imperasi penyiapan individu untuk berpartisipasi-aktif dalam kehidupan ekonomi kemasyarakatan dengan tujuan peningkatan kesejahteraan sosial bersama. Berdasar hal ini, Ibnu Sina mengharuskan pengarahan anak, setelah berhasil memahami al-Qur'an dan menguasai dasar-dasar kebahasaan, menuju penguasaan keterampilan (skill-teknik) sesuai dengan minat dan bakatnya. Kemudian di saat anak telah terampil, maka sebagai pembinaan lanjut adalah di beri tugas atau pekerjaan yang menghasilkan laba. Dengan hal ini sang anak akan mendapatkan dua manfaat: pertama, bila ia telah merasakan keasyikan kerja sesuai dengan keterampilannya dan memahami benar keuntungan yang dihasilkannya, maka ia akan terdorong untuk terus berkarya dan berprestasi. Kedua, ia akan menjadi terbiasa (enjoy) untuk mencari nafkah hidup, sebelum benar-benar saatnya tertuntut untuk itu [Ibnu Sina dalam Risalah al-Siyasab].

Tuntutan para ahli pendidikan Muslim terhadap perlunya pengarahan peserta didik untuk berpartisipasi-aktif dalam kehidupan ekonomi masyarakat membawa pada keharusan diversifikasi-pengajaran, agar masingmasing peserta didik dapat belajar hal yang sesuai dengan minat dan bakatnya sebagai bekal terjun ke dalam kancah kehidupan sosial. Mereka

${ }^{30}$ Ibnu Miskawaih, Tabdzib al-Akblaq... dalam Muhammad Jawwad Ridla... hlm. 214.

182 | FaLASIFA, Vol. 10 Nomor 1 Maret 2019 
menetapkan keharusan bagi guru untuk menyingkap potensi-potensi yang dimiliki peserta didiknya dan mengarahkannya, mengingat tidak semua jenis keterampilan itu bisa dengan mudah dikuasai peserta didik, melainkan hanya keterampilan yang sesuai dengan bakatnya. Sekiranya jenis-jenis keterampilan dan profesi dengan mudah bisa dikuasai hanya semata-mata karena dipelajari tanpa ada kaitannya dengan bakat, niscaya tidak akan ada orang yang tidak berketerampilan dan semua orang tentunya akan dapat memilih keterampilan dan profesi yang canggih. Oleh karena itu, guru dituntut untuk pandai-pandai memilihkan suatu keterampilan yang cocok dengan (bakat) peserta didiknya. Hendaknya guru melakukan assesment terhadap kecerdasan, minat dan bakat peserta didiknya. Dengan begitu guru akan mengetahui seberapa besar peluang yang dimiliki peserta didik untuk bisa menguasai keterampilan yang akan diajarkannya. Lebih jauh, pengajaranketerampilan benar-benar akan mendapatkan relevansi "psikologis", dan benar-benar efektif dan efisien [Ibnu Sina dalam Risalah al-Siyasah].

\section{TEORI BELAJAR AKHLAK PERSPEKTIF PENDIDIKAN ISLAM}

Setelah mengelaborasi enam rumusan teori Pendidikan Islam di atas, dengan mendasarkan kepada al-Qur'an dan al-Sunah serta khazanah pemikiran intelektual muslim, maka tulisan ini selanjutnya mengemukakan teori belajar yang sepadan dengan teori belajar behavioristik, yaitu teori belajar akblak. Pembentukan akhlak yang mulia merupakan salah satu misi yang diemban oleh Rasulullah SAW dalam menyebarkan agama Islam. Maka tulisan ini mencoba mengetengahkan teori belajar akhlak yang bersumber dari al-Qur'an dan al-Sunah karena akhlak merupakan standar ukuran dalam Islam tentang baik tidaknya individu.

Teori belajar akhlak merupakan teori belajar yang fokus utamanya adalah pembentukan tingkah laku individu muslim yang harapannya setelah mengalami proses belajar, individu muslim mempunyai tingkah laku yang sesuai dengan ketentuan dalam Islam. Akhlak merupakan tindakan ataupun sikap individu yang dilakukan secara spontanitas terhadap situasi tertentu tanpa adanya pertimbangan. Jadi, akhlak di sini merupakan perilaku reflek yang sudah terbentuk sekian lama, sehingga menjadi kebiasaan individu dalam merespon sesuatu kondisi tertentu. Misalnya, ketika individu melihat nenek tua hendak menyebrang jalan, maka di sinilah akan tampak akhlaknya, apakah ia tidak peduli dengan nenek tersebut, ataukah ia menghampiri nenek itu dan membantu menyeberangkan. Dalam teori belajar akhlak, terdapat tiga model pembelajaran; taqlid, tajribah wa al-kbata' dan 
M. Nafiur Rofiq

ta'wid. $^{31}$

Adapun penjelasan dari tiga model teori belajar akhlak tersebut secara berurutan dibahas sebagaimana paparan di bawah ini:

\section{Teori Taqlid (Imitasi/Peniruan) ${ }^{32}$}

Kebanyakan perilaku manusia dan kebiasaannya merupakan hasil tiruan dari orang yang ada di sekelilingnya. Proses belajar bisa berjalan dengan sempurna melalui imitasi (peniruan). Teori ini terealisasi ketika seseorang meniru orang lain dalam mengerjakan sesuatu maupun melafalkan suatu kata. Karena menurut Ibnu Sina terdapat Pengaruh tabi'iyah anak yang cenderung mengikuti dan meniru segala yang dilihat, dirasakan dan didengarnya. ${ }^{33}$

Al-Qur'an telah menyebutkan contoh-contoh yang menjelaskan bahwa manusia cenderung belajar dengan meniru apa yang dilihatnya. Di antaranya adalah ketika Qabil membunuh saudaranya Habil, dan ia tidak mengetahui bagaimana ia harus memperlakukan mayat saudaranya yang telah dibunuhnya. Maka Allah mengajarkan kepada Qabil dengan mengutus seekor burung Gagak yang menggali tanah untuk menguburkan bangkai burung Gagak lainnya yang telah mati. Dari sini Qabil belajar bagaimana mengubur mayat seperti difirmankan Allah SWT berikut:

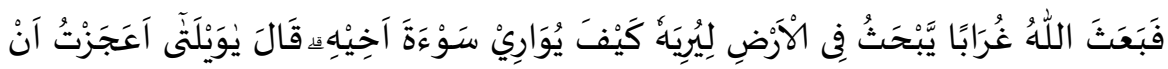

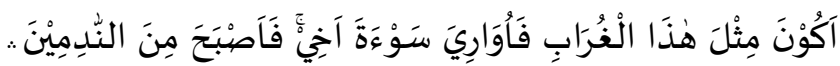

Kemudian Allah menyuruh seekor burung gagak menggali-gali di bumi untuk memperlihatkan kepadanya (Qabil) bagaimana seharusnya menguburkan mayat saudaranya. Berkata Qabil: "Adubai celaka aku, Mengapa Aku tidak mampu berbuat seperti burung gagak ini, lalu Aku dapat menguburkan mayat saudaraku ini?" Karena itu jadilah dia seorang diantara orang-orang yang menyesal. (QS. AlMaidah: 31).

Begitu juga dalam al-Sunnah, para sahabat belajar mengerjakan berbagai ibadah dan manasik dari Rasulullah dengan cara meniru apa yang dilakukan oleh Rasulullah. Seperti mengajarkan kaifiyah shalat. Rasululah mendemonstrasikan cara shalat di hadapan para sahabatnya, dengan tujuan agar mereka meni-

${ }^{31}$ Moh. Ustman Najati. Jiwa Manusia dalam Sorotan Al-Qur'an. Terj. Ibn Ibrahim. (Jakarta: CV. Cendekia Sentra, 2002), hlm. 207-216.

${ }^{32}$ Istilah taqlid dalam Islam biasanya digunakan dalam ilmu ushul fiqih yang mengkaji tentang proses penggalian hukum Islam. Akan tetapi peneliti di sini hanya mengadopsi istilah saja yang dikaitkan dengan belajar.

${ }_{33}$ Slamet Untung, Mubammad Sang Pendidik. (Semarang: Pustaka Rizki Putra, 2005), hlm. 166.

184 | FaLASIFA, Vol. 10 Nomor 1 Maret 2019 
runya. ${ }^{34}$ Beliau adalah figur ideal sebagai manusia sempurna yang dapat dilihat dari berbagai aspek kehidupannya. Karena dapat dipastikan Rasulullah mengedepankan keteladanan sebelum beliau sendiri menerjemahkannya dalam ungkapan verbal (kata-kata). ${ }^{35}$ Sehingga para sahabat meneladani beliau dalam setiap perilaku dan perkataannya. Bahkan Allah sendiri telah memerintahkan kepada kita untuk mengikuti perilaku Rasulullah sebagaimana firman Allah SWT berikut:

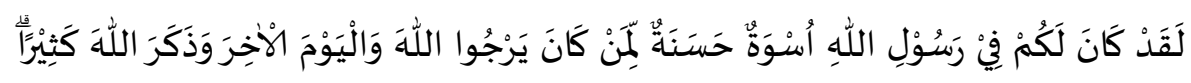

Sesungguhnya Telah ada pada (diri) Rasulullah itu suri teladan yang baik bagimu (yaitu) bagi orang yang mengharap (rahmat) Allah dan (kedatangan) bari kiamat dan dia banyak menyebut Allah. (QS. Al-Ahzab: 21).

Menurut al-Attas, ${ }^{36}$ taqlid di sini tidak hanya sebatas proses peniruan buta yang memandulkan kemampuan rasional dan intelektual seseorang. Sebaliknya, mempraktekkan taqlid atau menyerahkan pada otoritas tertentu, membutuhkan pengetahuan murni atas suatu masalah dalam rangka membedakan antara berbagai pandangan ahli mengenai hal itu. Jadi, menurut al-Attas, taqlid tidaklah berseberangan dengan belajar, tetapi merupakan suatu sifat alami dan positif pada tahap awal perkembangan pelajar atau seseorang yang tidak berkesempatan mengenyam pendidikan dan latihan yang cukup untuk memahami alasan dan bukti-bukti secara detail.

\section{Teori Tajribah wa al-Khatha' (Trial and Error)}

Manusia juga belajar melalui eksperimen pribadi. Dia akan berusaha secara mandiri untuk memecahkan problem yang dihadapinya. Terkadang beberapa kali ia melakukan kesalahan dalam memecahkan masalah, namun dia juga beberapa kali mencoba untuk melakukannya kembali. Sampai pada akhirnya dia mampu menyelesaikan permasalahannya dengan benar. Model semacam ini

${ }^{34}$ Teks Haditsnya: "Sesungguhnya Rasulullah SAW berdiri di atas mimbar. Lantas beliau bertakbir dan orang-orang yang berada di belakang beliau ikut bertakbir. Lalu Rasulullah ruku' untuk kemudian turun sambil berjalan mundur. Kemudian beliau sujud di ujung mimbar. Kemudian kembali [ke atas mimbar] sampai usai menunaikan shalatnya. Seusai shalat, beliau menghadap kepada orang-orang seraya bersabda: sesungguhnya aku berbuat seperti ini hanya bertujuan supaya kalian mengikuti aku dan supaya kalian mempelajari cara shalatku" (HR. Bukhari). Lebih lanjut lihat Bukhari, 1992, hlm. 124125 .

${ }^{35}$ Slamet Untung, Muhammad Sang Pendidik..., hlm. 160.

${ }^{36}$ Wan Daud, Wan Mohd Nor. Filsafat dan Praktik Pendidikan Islam Syed Naquib al-Attas, Terj. Hamid Fahmi. (Bandung: Mizan, 2003), hlm. 263.

FalASIFA, Vol. 10 Nomor 1 Maret 2019 | 185 
M. Nafiur Rofiq

disebut sebagai trial and error (coba dan salah). ${ }^{37}$

Dalam kehidupan sehari-hari, kita sering melakukan hal ini terhadap sesuatu baru yang belum kita ketahui cara pemecahannya. Rasulullah pun ternyata sudah mengisyaratkan teori trial and error ini dalam Hadisnya tentang penyemaian mayang kurma, sebagaimana hadis dari 'Aisyah, sebagai berikut:

"Sesunggubnya Rasulullah mendengar suara, lalu beliau bertanya: "ini suara apa?”. Para sahabat menjawab: orang-orang sedang menyerbukkan kurma. Maka Nabi bersabda: "seandainya mereka tidak melakukannya, tentu itu lebih baik”. Maka para sababat tidak melakukan hal itu lagi tahun ini, ternyata mereka mengalami gagal panen. Kemudian mereka memberitahu Nabi, lalu Nabi bersabda: "jika sesuatu itu termasuk perkara dunia kalian, maka itu terserab kalian. Akan tetapi jika itu termasuk urusan agama kalian, maka tanyalah kepada saya” (HR. Ibnu Majah)

Hadis di atas menyebutkan bahwa Nabi SWA menduga penyerbukan yang dilakukan oleh para sahabat dengan mengawinkan sari bunga laki-laki (serbuk sari) pada sari bunga perempuan (putik) tidak berguna. Maka beliau berpendapat hal tersebut tidak perlu dilakukan. Sabda beliau: “...jika sesuatu itu termasuk perkara dunia kalian, maka itu terserah kalian. Akan tetapi jika itu termasuk urusan agama kalian, maka tanyalah kepada saya”.

Hal ini mengisyaratkan bahwa pentingnya melakukan usaha coba-coba salah, jika menggunakan cara ini salah, maka ganti kepada cara lain yang lebih baik hasilnya. Teori ini hanya berlaku bagi hal-hal yang bersifat praktis yang tidak membutuhkan pemikiran panjang dan lebih bersifat senso-motorik. Hal ini berguna bagi peserta didik yang belajar untuk menemukan jawaban-jawaban baru bagi situasi yang baru dan juga sebagai solusi problem yang dihadapinya dalam kehidupan praktis.

Dalam hal ini, teori belajar melalui tajribah wa al-khatha' merupakan usaha yang dilakukan untuk menyelesaikan masalah yang berkaitan dengan urusan dunia atau kehidupan aplikatif yang tidak membutuhkan pemikiran yang panjang dan bersifat praktis.

\section{Teori Ta'wid (Pembiasaan)}

Seseorang dikatakan belajar dengan ta'wid (pembiasaan) jika ada stimulus indrawi yang merangsangnya. Ketika itulah seseorang menanggapi stimulus indrawi yang disebut sebagai respon. Respon ini kemudian diikuti dengan sti-

${ }^{37}$ Ibid, hlm. 209.

186 | FaLASIFA, Vol. 10 Nomor 1 Maret 2019 
mulus netral. Hal ini seperti yang dipaparkan Hasan Langgulung ${ }^{38}$ yang menyebutkan terdapat beberapa syarat yang harus dipenuhi agar proses belajar itu bisa berlaku, yaitu:

a. Harus ada perangsang (stimulus). Perangsang ini harus mudah dipahami oleh orang yang belajar. Misalnya, soal-soal yang diberikan oleh guru;

b. Pelajar harus bergerak balas (respon) kepada perangsang tersebut. Kalau pelajar tidak berbuat apa- apa ketika diberi soal, maka si pelajar tadi tidak dikatakan belajar;

c. Gerak balas itu diberi peneguh (tsawab) agar gerak balas itu bersifat kekal.

Misalnya, guru menanyakan kepada siswanya, apa nama buah ini? Bila siswa menjawab buah jeruk, dan memang benar, kemudian guru tersenyum dan mengatakan bahwa jawaban kamu benar. Maka ucapan benar tadi merupakan peneguhan terhadap jawaban (gerak balas) siswa terhadap soal guru (perangsang). Dalam psikologi ada teori belajar yang disebut dengan reward dan reinforcement.

Dalam al-Qur'an, teori ini bisa diambil dari pentahapan proses pengkondisian umat Islam agar mempunyai kepribadian yang islami. Bagaimana Islam mengkondisikan umatnya yang ketika itu masih menyembah berhala, menjadi manusia yang hanya mentauhidkan Allah semata. Islam mampu mengkondisikan bangsa Arab menjadi bangsa yang mempunyai peradaban yang tinggi dan kepribadian yang mulia. Mampu menciptakan kehidupan yang tidak berorientasi pada materialisme dan hedonisme, melainkan kepada kehidupan yang beragama (theokrasi). Tentunya dalam pengkondisian ini, Islam memberikan tsawab bagi umatnya, yaitu berupa balasan pahala dan surga kelak di akhirat nanti dan adzab bagi yang melanggarnya (walaupun bersifat abstrak).

\section{DAFTAR PUSTAKA}

Al-Syaibani, Omar Muhammad al-Toumy, Filsafat Pendidikan Islam, terj. Hasan Langgulung, 1979, Jakarta: Bulan Bintang.

Al-Syalabi, Ahmad, 1961. Tarikh al-Tarbiyah al-Islamiyah, Kairo, tnp, cet. II.

Arifin, M, 1987. filsafat pendidikan Islam, Jakarta: Bina Aksara.

Assegaf, Abd. Rahoman, 2013. Aliran Pemikiran Pendidikan Islam: Hadbarah

Keilmuan Tokoh Klasik sampai Modern, Jakarta: PT. Raja Grafindo Persada.

Cetakan ke-2.

Baharuddin dan Esa Nur Wahyuni, 2010. Teori Belajar dan Pembelajaran,

${ }^{38}$ Hasan Langgulung, Asas-Asas Pendidikan Islam. (Jakarta: Al-Husna, 1988), hlm. 362.

FaLASIFA, Vol. 10 Nomor 1 Maret 2019 | 187 
M. Nafiur Rofiq

Yogyakarta: Ar-Ruzz Media.

Daud, Wan, Wan Mohd Nor, 2003. Filsafat dan Praktik Pendidikan Islam Syed Naquib al-Attas, Terj. Hamid Fahmi. Bandung: Mizan.

Khaldun, Ibnu, 1960. al-Muqaddimah, jilid I, Ali Abdul Wahid Wafi (ed.), Kairo:

Nasyr Lajnati al-Bayan al-Arabi,

Langgulung, Hasan, 1988. Asas-Asas Pendidikan Islam. Jakarta: Al-Husna.

Miskawih, Ibnu, 1961. Tahdzib al-Akhlaq wa Tathbir al-A'raq, Beirut: tnp.,

Muhaimin, 2014. Pengembangan Kurikulum Pendidikan Agama Islam di Sekolah, Madrasah, dan Perguruan Tinggi, Jakarta: PT. Raja Grafindo Persada, Cetakan ke-6.

Najati, Moh. Ustman. 2002. Jiwa Manusia dalam Sorotan Al-Qwr'an. Terj. Ibn Ibrahim. Jakarta: CV. Cendekia Sentra.

Nizar, Samsul, 2002. Filsafat Pendidikan Islam: Pendekatan Historis, Teoritis dan Praktis. Jakarta: Ciputat Pers.

Ridla, Muhammad Jawwad, 2002. Tiga Aliran Utama Teori Pendidikan Islam: Perspektif Sosiologis-Filosofis, Diterjemahkan oleh Mahmud Arif, Yogyakarta: Tiara Wacana.

Surachmad, Winarno, 1978. Dasar dan Teknik Research, Bandung: Tarsito.

Syar'i, Ahmad, 2005. Fislafat Pendidikan Islam, Jakarta: Pustaka Firdaus.

Tim Dosen IAIN Sunan Ampel Malang. 1996. Dasar-Dasar Kependidikan Islam: Suatu Pengantar Ilmu Pendidikan Islam. Surabaya: Karya Abditama.

Untung, Slamet, 2005. Mubammad Sang Pendidik. Semarang: Pustaka Rizki Putra 